\title{
The interplay between HIF-1a and noncoding RNAs in cancer
}

\author{
Xiafeng Peng ${ }^{1,2+}$, Han Gao ${ }^{3 \dagger}$, Rui Xu ${ }^{4}$, Huiyu Wang ${ }^{1}$, Jie Mei ${ }^{1 *}$ (D) and Chaoying Liu ${ }^{1 *}$
}

\begin{abstract}
Hypoxia is a classic characteristic of the tumor microenvironment with a significant impact on cancer progression and therapeutic response. Hypoxia-inducible factor-1 alpha (HIF-1a), the most important transcriptional regulator in the response to hypoxia, has been demonstrated to significantly modulate hypoxic gene expression and signaling transduction networks. In past few decades, growing numbers of studies have revealed the importance of noncoding RNAs (ncRNAs) in hypoxic tumor regions. These hypoxia-responsive ncRNAs (HRNs) play pivotal roles in regulating hypoxic gene expression at the transcriptional, posttranscriptional, translational and posttranslational levels. In addition, as a significant gene expression regulator, ncRNAs exhibit promising roles in regulating HIF-1a expression at multiple levels. In this review, we briefly elucidate the reciprocal regulation between HIF-1a and ncRNAs, as well as their effect on cancer cell behaviors. We also try to summarize the complex feedback loop existing between these two components. Moreover, we evaluated the biomarker potential of HRNs for the diagnosis and prognosis of cancer, as well as the potential clinical utility of shared regulatory mechanisms between HIF-1a and ncRNAs in cancer treatment, providing novel insights into tumorigenicity, which may lead to innovative clinical applications.
\end{abstract}

Keywords: HIF-1a, ncRNA, carcinogenesis, clinical practice

\section{Background}

Hypoxia is a common hallmark in the tumor microenvironment, and its occurrence originates from an imbalance in the supply and consumption of oxygen by rapidly growing tumors $[1,2]$. Intratumoral hypoxic conditions stimulate genetic programs that facilitate cellular adaptations to this environmental pressure, subsequently conferring more aggressive phenotypes to cancer cells, such as altered metabolism, augmented survival, invasion, migration, angiogenesis, and resistance to ionizing radiation and various chemotherapies [3-5]. Among the various transcription factors participating in the regulation of tumor cell fate, hypoxia-inducible factor-1 alpha (HIF-1 $\alpha)$, the most important transcriptional regulator in response to hypoxia, has been robustly demonstrated to extensively modulate hypoxic gene expression and the signaling transduction networks related to the aforementioned adaptations $[6,7]$.

\footnotetext{
* Correspondence: meijie1996@njmu.edu.cn; liuchaoying666@163.com

${ }^{+}$Xiafeng Peng and Han Gao contributed equally to this work.

'Department of Oncology, Wuxi People's Hospital Affiliated to Nanjing

Medical University, 299 Qingyang Road, Wuxi 214023, China

Full list of author information is available at the end of the article
}

Under normoxic conditions, the conserved proline residues 402 and 564 of HIF- $1 \alpha$ are hydroxylated by prolyl hydroxylase domain enzymes (PHDs) that utilize $\mathrm{O}_{2}$ [8]. Thereafter, the von Hippel Lindau (VHL) tumor suppressor functions as an E3 ubiquitin ligase to mediate the ubiquitination of HIF- $1 \alpha$ by specifically binding to these two prolyl-hydroxylated residues, eventually leading to rapid proteasomal degradation of HIF- $1 \alpha$ protein $[9,10]$. In addition to the regulation of the degradation of HIF- $1 \alpha$, the transcriptional activity of HIF- $1 \alpha$ is also regulated by another asparaginyl hydroxylase, hypoxia-inducible factor 1, alpha subunit inhibitor (FIH1), which hydroxylates an asparagine residue of HIF- $1 \alpha$ in its C-terminal transactivation domain $[11,12]$ and therefore blocks the combination of HIF with the transcriptional coactivator $\mathrm{CBP} / \mathrm{p} 300$, eventually inhibiting HIF- $1 \alpha$ transcriptional activation [13] (Fig. 1). In hypoxic conditions, oxygen deprivation halts the oxygen-dependent hydroxylation activity of PHDs and FIH to elicit the stabilization of HIF-1 $\alpha$, further enabling HIF- $1 \alpha$ to translocate to the nucleus and complex with HIF-1 $\beta$ and the transcriptional coactivator CBP/ p300 to recognize hypoxia-response elements (HREs) in

(C) The Author(s). 2020 Open Access This article is distributed under the terms of the Creative Commons Attribution 4.0 International License (http://creativecommons.org/licenses/by/4.0/), which permits unrestricted use, distribution, and 


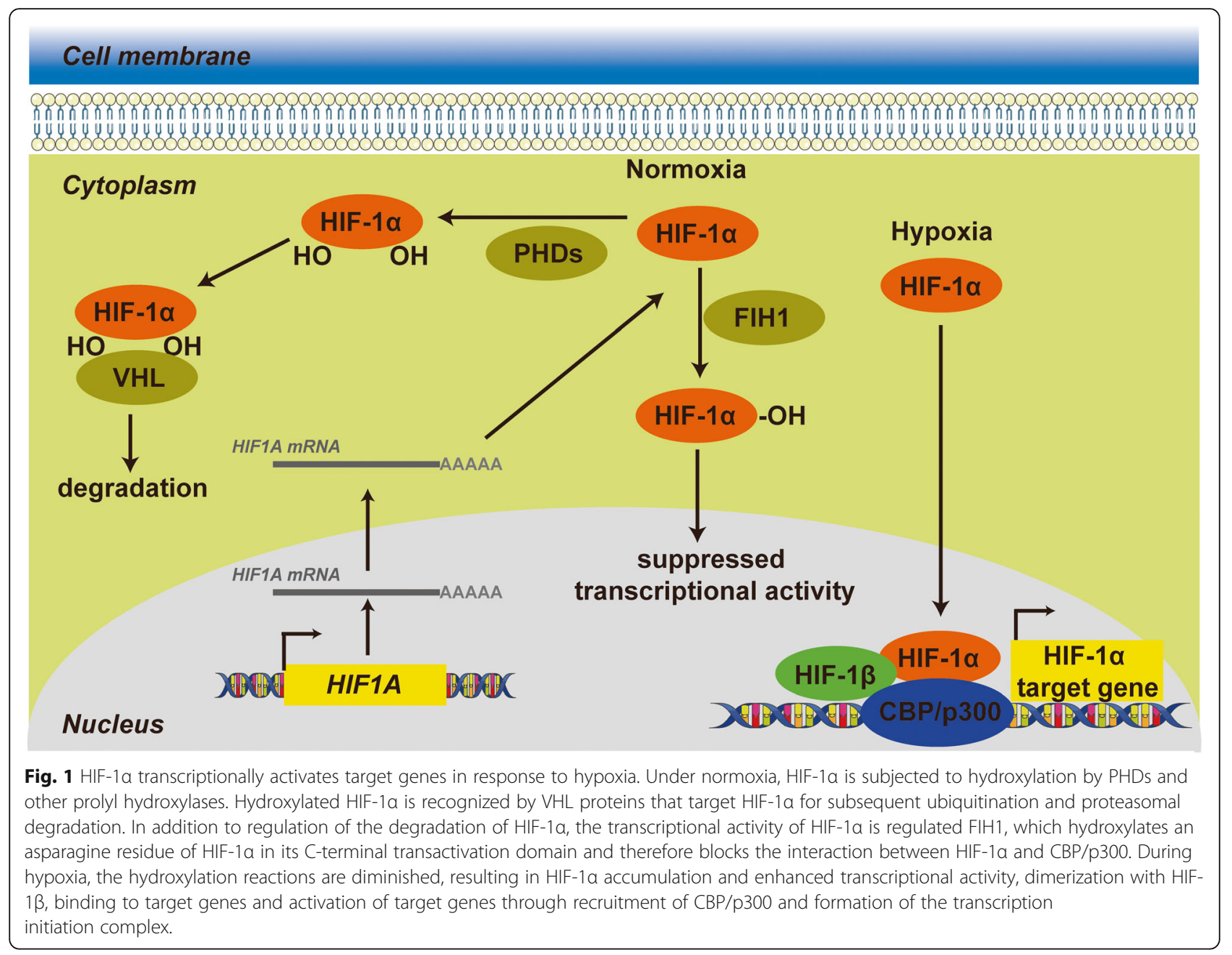

the promoters of target genes for subsequent transcription [14, 15] (Fig. 1).

Noncoding RNAs (ncRNAs) are a group of RNAs that occupy more than $95 \%$ of the human transcriptome without the capacity to encode proteins [16]. Specifically, ncRNAs can be categorized into two groups, small ncRNAs and long ncRNAs (lncRNAs), according to their length, with a cut-off at 200 nucleotides. Due to their lack of protein-coding capacity, ncRNAs have been regarded as transcriptional "noise" for some time. However, a growing number of studies have demonstrated that ncRNAs have critical biological effects on both physiological and pathological processes $[17,18]$, especially in the field of cancer research $[19,20]$.

To date, current studies of ncRNAs have mainly concentrated on microRNAs (miRNAs), IncRNAs, and circular RNAs (circRNAs). MiRNAs, which are approximately 20 to 24 nucleotides in length, are a well-known group of small ncRNAs that epigenetically or posttranscriptionally regulate the expression of target mRNAs by imperfectly base pairing with the mRNA 3'-untranslated region (3'-
UTR) of target mRNAs. LncRNAs, which have transcripts of more than 200 nucleotides in length, exhibit multiple functions in regulating gene expression through chromatin modification and transcriptional and posttranscriptional regulation [21-23]. Although circRNAs belong to the lncRNA family, researchers tend to discuss them separately, distinguishing them from lncRNAs due to their unique structure.

More than one thousand target genes have been reported to be regulated by HIF- $1 \alpha$ to mediate the phenotypes induced by hypoxia $[24,25]$. Among these, ncRNAs modulated by hypoxia signaling, which are termed hypoxia-responsive ncRNAs (HRNs), are especially noteworthy, and there are emerging studies concentrated on the exploration of crosstalk between ncRNAs and HIF- $1 \alpha$ in multiple tumorigenesis processes. In this review, we briefly elucidate the reciprocal regulation between HIF- $1 \alpha$ and ncRNAs in terms of transcription, translation, and protein stability, as well as their effect on the various biological behaviors of tumor cells. In addition, we also attempt to summarize the 
variegated feedback loop existing in these two components, which is different from simple unidirectional regulation. Finally, we evaluate the potential of prospective HRN biomarkers for the diagnosis and prognosis of cancer, as well as the potential clinical application of regulatory mechanisms shared between HIF- $1 \alpha$ and ncRNAs in cancer treatment.

\section{Regulation of ncRNAs by HIF-1a}

Given the relevance of HIF pathways to tumor pathogenesis and the pivotal roles of ncRNAs in gene expression, it is not surprising that substantial effort has been directed toward defining the transcriptional output of ncRNAs in hypoxia-associated malignant progression in the past few years. According to their interplay with the HIF complex, HRNs can be categorized into participating in HIF- $1 \alpha$-mediated direct regulation and HIF- $1 \alpha-$ mediated indirect regulation. It is well appreciated that the HIF complex is a crucial transcription factor coordinating the cellular transcriptional response under hypoxic stress [26].

In HIF- $1 \alpha$-mediated direct regulation, HIF- $1 \alpha$ directly regulates ncRNAs at the transcriptional level through HREs, which usually reside within the promoter regions of the ncRNAs [27]. In addition, several studies have described hypoxic induction of lncRNAs without the direct involvement of HIF on their promoters. These indirect regulations seem to be achieved through epigenetic mechanisms. Not surprisingly, as an integral hypoxic transcription factor, the HIF complex transactivates the expression of multiple genes, including those involved in epigenetic modifications by histone deacetylases (HDACs) [26]. As a novel hotspot of the ncRNA field, hypoxia-responsive circRNAs (HRCs) have been shown to be of great importance. However, unlike miRNAs and lncRNAs, the mechanisms of HIF-1 $\alpha$-mediated HRC expression are not fully understood [28]. Similarly, several studies uncovered that HIF- $1 \alpha$ can directly regulate circRNAs at the transcriptional level through HREs, but more mechanisms have not been reported [29].

\section{Regulation of miRNAs by HIF-1a}

Recently, the number of HRNs that have been identified is expanding rapidly, illustrating the complexity of hypoxia-responsive gene reprogramming and the importance of reconsidering the involvement of the noncoding genome in this adaption [30,31]. MiRNAs are the most studied subgroup of ncRNAs, and hypoxiaresponsive miRNAs (HRMs) have exhibited promising oncogenic and/or tumor-suppressive functions in the oncogenesis and development of cancers [32]. In this section, we systematically discuss the regulatory mechanism of ncRNAs by HIF- $1 \alpha$. As a result, we summarize the functions of miR-210 in tumors in Table 1 as well as other HRMs and their roles in Table 2.

\section{Regulation of miR-210 expression by HIF-1a}

Among all the miRNAs regulated by hypoxia through HIF-1 $\alpha$ signaling, the most studied HRM is miR-210 [74-76]. Numerous studies aiming at the multifarious genes targeted by HIF- $1 \alpha$-induced miR-210 overexpression have highlighted the broad involvement of this mechanism in intricate cancer pathologies, including proliferation [33, 45, 46], apoptosis [34], angiogenesis [35], autophagy [36], metastasis [37-39], and radioresistance $[40,47]$.

Most studies have uncovered the oncogenic role of miR-210 in human cancers. For instance, given that miR-210 expression can be altered by the HIF- $1 \alpha / \mathrm{VHL}$ transcriptional system and the inverse correlation of miR-210 expression with outcome variables as an independent prognostic marker in breast cancer [41] and clear cell renal cell cancer [42], Yu et al. further hypothesized and identified that miR-210 mediated HIF-1 $\alpha$ induced epithelial-mesenchymal transition (EMT) to drive invasion, recurrence, and metastasis of gastric cancer by regulating the expression of homeobox A9 (HOXA9), a transcription factor which may regulate gene expression, morphogenesis, and differentiation [43]. In both ovarian cancer specimens and cell lines under hypoxic conditions, increasing miR-210 expression shows a positive correlation with HIF- $1 \alpha$ overexpression and indicates more aggressive and anti-apoptotic outcomes characterized by a higher tumor stage, larger postoperative residual tumor size, augmented cell proliferation and clone generation. This oncogenic effect of miR-210 in vivo is dependent on the inhibition of protein tyrosine phosphatase, non-receptor type 1 (PTPN1) [33]. Moreover, there is an interesting phenomenon in which increasing the release of exosomes containing miR-210 by breast cancer cells promotes their invasion and assists in their survival, which is hypoxically mediated by the HIF-1 $\alpha$ oxygen-sensing system [44].

However, McCormick et al. [48] found an unexpected relationship between HIF- $1 \alpha$-induced miR-210 expression and favorable clinicopathological factors, such as reduced proliferation, decreased tumor stage and grade, and improved survival, which is in contrast with the disadvantageous outcomes in clear cell renal cell cancer [42, 49]. Similarly, in neuroblastoma cells, HIF-1 $\alpha$ dependent induction of miR-210 triggered by oxygen/ glucose deprivation has been demonstrated to target the 3'UTR of B-cell CLL/lymphoma 2 (Bcl-2) and sequentially promote hypoxia-induced neural apoptosis [50]. Collectively, the role of HIF- $1 \alpha$-induced miR-210 has different roles in various cancers, which need to be further explored to solve this mystery. 
Table 1 Summarization of the roles and functions of miR-210 in human cancers

\begin{tabular}{|c|c|c|c|c|}
\hline Role in cancer & Cancer types & Targets & Functions & References \\
\hline oncogene & ovarian cancer & PTPN1 & promotes proliferation, inhibits apoptosis & [33] \\
\hline oncogene & $\begin{array}{l}\text { hepatocellular } \\
\text { cancer }\end{array}$ & AlFM3 & promotes proliferation, inhibits apoptosis and radiosensitivity & [34] \\
\hline oncogene & lung cancer & $\begin{array}{l}\text { FGFRL1, E2F3, VMP1, RAD52, } \\
\text { SDHD }\end{array}$ & promotes angiogenesis & [35] \\
\hline oncogene & colon cancer & $\mathrm{BCl}-2$ & enhances autophagy and reduces radiosensitivity & [36] \\
\hline oncogene & breast cancer & N.A. & promotes proliferation, invasion and migration & [37] \\
\hline oncogene & $\begin{array}{l}\text { hepatocellular } \\
\text { cancer }\end{array}$ & VMP1 & promotes migration and invasion & [38] \\
\hline oncogene & prostate cancer & TNIP1, SOCS1 & promotes EMT, invasion and migration & [39] \\
\hline oncogene & glioma & MNT & $\begin{array}{l}\text { promotes hypoxic glioma stem cells stemness and } \\
\text { radioresistance }\end{array}$ & [40] \\
\hline oncogene & breast cancer & N.A. & N.A. & [41] \\
\hline oncogene & renal cancer & ISCU1/2 & N.A. & [42] \\
\hline oncogene & gastric cancer & HOXA9 & inhibits EMT, invasion and metastasis & [43] \\
\hline oncogene & breast cancer & N.A. & promotes survival and invasion & [44] \\
\hline $\begin{array}{l}\text { tumor } \\
\text { suppressor }\end{array}$ & esophageal cancer & FGFRL1 & inhibits survival and proliferation & [45] \\
\hline $\begin{array}{l}\text { tumor } \\
\text { suppressor }\end{array}$ & laryngocarcinoma & FGFRL1 & inhibits proliferation & [46] \\
\hline $\begin{array}{l}\text { tumor } \\
\text { suppressor }\end{array}$ & esophageal cancer & N.A. & promotes differentiation, inhibits radioresistance & [47] \\
\hline $\begin{array}{l}\text { tumor } \\
\text { suppressor }\end{array}$ & renal cancer & ISCU & N.A. & [48] \\
\hline $\begin{array}{l}\text { tumor } \\
\text { suppressor }\end{array}$ & renal cancer & E2F3 & inhibits proliferation, induces multinucleation & [49] \\
\hline $\begin{array}{l}\text { tumor } \\
\text { suppressor }\end{array}$ & neuroblastoma & $\mathrm{BCl}-2$ & promotes apoptosis & [50] \\
\hline
\end{tabular}

\section{Regulation of other HRM expression by HIF-1a}

Positive regulation of HIF- $1 \alpha$ on miRNAs is common in cancer progression. The most likely mechanism is that HIF- $1 \alpha$ translocates to the nucleus and forms a complex with HIF-1 $\beta$ and CBP/p300 to recognize the HREs in the promoters of primary miRNAs (pri-miRNAs) for subsequent transcription [77]. The cigarette-smoke-induced malignant transformation of bronchial epithelial cells , including characteristics of amplified colony formation, invasion and migration capacities, is dependent on HIF- $1 \alpha-$ induced miR-21 upregulation, which subsequently inhibits phosphatase and tensin homolog (PTEN), a classic tumor suppressor, to activate the Akt/NF- $\mathrm{kB}$ pathway [51], while in gastric cancer cells, PTEN inhibition caused by HIF- $1 \alpha-$ mediated miR-382 expression inversely restrains the Akt/ mTOR signaling pathway, conferring miR-382 with angiogenic effects [52]. Similarly, HIF- $1 \alpha$-induced activation of miR-224 targets Ras association domain family member 8 (RASSF8), stimulating NF- $\mathrm{kB}$ transcriptional activity and subcellular distribution to confer gastric cancer with more aggressive phenotypes [53]. An indirect interaction distinguished from the aforementioned direct interaction between HIF-1 $\alpha$ and miRNAs is elicited by Drosha, an RNase III enzyme and the key factor for nuclear processing of pri-miRNAs [78]. Specifically, in glioblastoma, HIF-1 $\alpha$ promotes miR-215 biogenesis by enhancing the incorporation of pri-miR-215 into the microprocessor Drosha; then, increased miR-215 directly targets the epigenetic regulator lysine (K)-specific demethylase 1B (KDM1B) to enhance adaptation to the hypoxic niche [54].

Not limited to positive regulatory mechanisms, HIF- $1 \alpha$ can also negatively regulate miRNA expression mostly in an indirect HIF-1 $\alpha$-mediated manner. In hepatocellular carcinoma, vasodilator-stimulated phosphoprotein (VASP) acts as a tumor premotor and its overexpression at the transcriptional level is mediated by direct binding of HIF- $1 \alpha$ to HREs in the VASP promoter region. Moreover, miR-204 is inhibited by HIF-1 $\alpha$ to upregulate VASP at the posttranscriptional level, providing a typical instance in which HIF-1 $\alpha$ and suppressed miRNAs synergistically regulate the same gene in different ways. However, the reason why HIF- $1 \alpha$ negatively regulates miR-204 expression is not clear [65]. Li et al. demonstrated that downregulated miR-34a was necessary for 
Table 2 List of hypoxia-responsive miRNAs excepting miR-210

\begin{tabular}{|c|c|c|c|c|c|c|}
\hline MiRNAs & Cancer types & $\begin{array}{l}\text { Status upon } \\
\text { hypoxia }\end{array}$ & Regulatory mechanisms & Targets & Functions & References \\
\hline miR-21 & lung cancer & upregulation & transcriptional activation & PTEN & $\begin{array}{l}\text { promotes colony formation, invasion and } \\
\text { migration }\end{array}$ & [51] \\
\hline miR-382 & gastric cancer & upregulation & transcriptional activation & PTEN & $\begin{array}{l}\text { promotes proliferation, migration and } \\
\text { angiogenesis }\end{array}$ & [52] \\
\hline miR-224 & gastric cancer & upregulation & transcriptional activation & RASSF8 & promotes growth, migration and invasion & [53] \\
\hline miR-215 & glioblastoma & upregulation & $\begin{array}{l}\text { transcriptinal proccessing via } \\
\text { Drosha }\end{array}$ & KDM1B & $\begin{array}{l}\text { promotes growth and neurospheres } \\
\text { formation }\end{array}$ & [54] \\
\hline miR-494 & lung cancer & upregulation & transcriptional activation & PTEN & promotes migration & [55] \\
\hline miR-145 & bladder cancer & upregulation & transcriptional activation & N.A. & promotes apoptosis & [56] \\
\hline miR-191 & breast cancer & upregulation & transcriptional activation & $\begin{array}{l}\text { TGF } \beta 2 \\
\text { HuR }\end{array}$ & $\begin{array}{l}\text { promotes proliferation, migration and } \\
\text { survival }\end{array}$ & [57] \\
\hline miR-27a & gastric cancer & upregulation & transcriptional activation & N.A. & $\begin{array}{l}\text { promotes proliferation, survival, multidrug } \\
\text { resistance }\end{array}$ & [58] \\
\hline miR-424 & breast cancer & upregulation & transcriptional activation & PDCD4 & $\begin{array}{l}\text { inhibits apoptosis and sensitivity to } \\
\text { chemotherapy }\end{array}$ & [59] \\
\hline miR-21 & pancreatic cancer & upregulation & transcriptional activation & N.A. & promotes proliferation, inhibits apoptosis & [60] \\
\hline miR-185 & pancreatic cancer & upregulation & transcriptional activation & N.A. & N.A & [61] \\
\hline $\begin{array}{l}\text { miR-210- } \\
3 p\end{array}$ & oral carcinoma & upregulation & transcriptional activation & RGMA & promotes proliferation & [62] \\
\hline miR-21 & oral carcinoma & upregulation & transcriptional activation & N.A. & promotes migration and invasion & [63] \\
\hline miR-107 & gastric cancer & upregulation & N.A. & N.A. & N.A. & [64] \\
\hline miR-204 & $\begin{array}{l}\text { hepatocellular } \\
\text { cancer }\end{array}$ & downregulation & N.A. & VASP & inhibits EMT, migration and invasion & [65] \\
\hline miR-34a & colorectal cancer & downregulation & transcriptional inhibition & PPP1R11 & inhibits EMT, invasion and migration & [66] \\
\hline $\begin{array}{l}\text { miR- } \\
548 \text { an }\end{array}$ & pancreatic cancer & downregulation & $\begin{array}{l}\text { transcriptional suppression } \\
\text { via } \mathrm{HDAC1}\end{array}$ & Vimentin & inhibits the proliferation and invasion & [67] \\
\hline $\begin{array}{l}\text { miR- } \\
\text { 200b }\end{array}$ & pan-cancer & downregulation & $\begin{array}{l}\text { transcriptinal proccessing via } \\
\text { Dicer }\end{array}$ & $\mathrm{ZEB} 1 / 2$ & inhibits EMT and invasion & [68] \\
\hline miR-33a & $\begin{array}{l}\text { hepatocellular } \\
\text { cancer }\end{array}$ & downregulation & N.A. & Twsit1 & inhibits EMT and invasion & [69] \\
\hline miR-205 & prostate cancer & downregulation & transcriptional inhibition & ZEB1/2 & $\begin{array}{l}\text { inhibits EMT, motility, stemness and cancer- } \\
\text { associated fibroblasts reactivity }\end{array}$ & [70] \\
\hline miR-101 & prostate cancer & downregulation & transcriptional inhibition & $\mathrm{EZH} 2$ & inhibits invasion, migration, proliferation & [71] \\
\hline $\begin{array}{l}\operatorname{miR}-224- \\
3 p\end{array}$ & $\begin{array}{l}\text { glioblastoma, } \\
\text { astrocytoma }\end{array}$ & downregulation & N.A. & ATG5 & $\begin{array}{l}\text { inhibits mobility, promotes } \\
\text { chemosensitivity }\end{array}$ & [72] \\
\hline miR-15a & lung cancer & downregulation & N.A. & N.A. & N.A. & [73] \\
\hline
\end{tabular}

hypoxia-induced EMT, invasion and migration in colorectal cancer cells. HIF- $1 \alpha$ can directly inhibit the expression of miR-34a in p53-defective colorectal cancer cells, whereas the level of miR-34a is increased in p53proficient colorectal cancer cells under hypoxia [66]. HIF- $1 \alpha$ could recruit HDAC1 to the promoter of primiR-548an to transcriptionally suppress miR-548an expression, resulting in the upregulation of the EMT marker vimentin, which facilitates the proliferation and invasion of pancreatic cancer cells [67]. Dicer, an RNase III enzyme responsible for cytoplasmic processing of precursor miRNA [79], is frequently interfered with by HIF- $1 \alpha$ in an indirect manner [68]. A previous study of breast cancer also found that the HIF-1/2 $\alpha$-dependent EGFR-AGO2 interaction under hypoxic stress probably triggers AGO2-Y393 phosphorylation to inhibit the binding of Dicer to AGO2, which disrupts the formation of the RISC-loading complex required for pre-miRNA processing of tumor-suppressive miRNAs [80].

In addition, the expression of various miRNAs, including miR-33a [69], miR-494 [55], miR-145 [56], miR-191 [57], miR-27a [58], miR-424 [59], miR-205 [70], miR-21 [60], miR-185 [61], miR-101 [71], miR-210-3p [62], miR224-3p [72], miR-15a [73], miR-21 [63], and miR-107 [64], has been proven to be HIF- $1 \alpha$-dependent in the progression of various cancers. These findings suggest 
that the HIF-1 $\alpha$-induced oncogenic effect is caused by transcriptional activation of oncogenic HRMs and inhibition of tumor-suppressive miRNAs to some extent.

\section{Regulation of IncRNAs by HIF-1a}

It is well appreciated that the HIF complex is a crucial transcription factor coordinating the cellular transcriptional response under hypoxic stress. According to their interplay with the HIF complex, hypoxia-responsive lncRNAs (HRLs) can be categorized into HIF-dependent and HIF-independent. We summarize the regulatory mechanisms underlying the HIF- $1 \alpha$-altered expression of HRLs in Table 3.

\section{Direct regulation of HRL transcription by HIF-1a}

Similar to the classical interactive mode between HIF- $1 \alpha$ and miRNAs, HIF- $1 \alpha$ can also directly interact with the HREs in the IncRNA BC005927 promoter region, inducing lncRNA BC005927 to play its oncogenic role in gastric cancer by upregulating EPH receptor B4 (EPHB4) [81]. In addition, HIF-1 $\alpha$-mediated direct interactions regulate the expression of numerous lncRNAs, including lncRNA BX111 [82], IncRNA UCA1 [83, 84], IncRNA FALEC [85], lncRNA MALAT1 [86], lncRNA ANRIL [87], and IncRNA NUTF2P3-001 [88], all of which play key roles in the development of tumors. Knowing of the existence of a direct interaction of HIF- $1 \alpha$ and the HRE region existing in the
IncRNA HOTAIR promoter in non-small-cell lung cancer [89], Bhan et al. argued that synchronously with this interaction, MLL1 and CBP/p300 are recruited to the lncRNA HOTAIR promoter region, cooperating with HIF- $1 \alpha$ to evoke the HOTAIR gene and promote tumorigenesis [90].

\section{Indirect regulation of HRL transcription by HIF-1a}

Due to the inability of researchers to identify a HIF- $1 \alpha$ binding motif in the MEG3 core promoter, Ruan et al. speculated that HIF- $1 \alpha$ activated lncRNA MEG3 in an indirect manner in human umbilical vein endothelial cells, in which $\mathrm{CBP} / \mathrm{p} 300$ recruitment for cAMP responsive element binding protein 1 (CREB) transcriptional activation is also required [91]. Although HIF-1 $\alpha$ itself can promote lncRNA H19 expression by interacting physically, the knowledge of a concurrent activation pathway of lncRNA H19 expression depending on the interaction between HIF- $1 \alpha$-induced SP1 and the H19 promoter in aggressive glioblastoma cells further expands existing understanding [92]. In addition, HIF-1 $\alpha$-induced IncRNA expression regulation can be implemented by HDAC3. IncRNA LET is repressed by HDAC3 and contributes to hypoxia-mediated hepatocellular carcinoma metastasis [93].

\section{Regulation of circRNAs by HIF-1a}

Although belonging to the lncRNA family, circRNAs are always discussed separately due to their unique structure

Table 3 List of hypoxia-responsive IncRNAs

\begin{tabular}{|c|c|c|c|c|c|}
\hline LncRNAs & Cancer types & $\begin{array}{l}\text { Status upon } \\
\text { hypoxia }\end{array}$ & Regulatory mechanisms & Functions & References \\
\hline $\begin{array}{l}\text { IncRNA } \\
\text { BC005927 }\end{array}$ & gastric cancer & upregulation & transcriptional activation & promotes invasion and metastasis & {$[81]$} \\
\hline IncRNA BX111 & pancreatic cancer & upregulation & transcriptional activation & $\begin{array}{l}\text { promotes EMT, proliferation, migration } \\
\text { and invasion }\end{array}$ & {$[82]$} \\
\hline IncRNA UCA1 & osteosarcoma & upregulation & transcriptional activation & promotes growth & {$[83]$} \\
\hline IncRNA UCA1 & bladder cancer & upregulation & transcriptional activation & $\begin{array}{l}\text { promotes proliferation, migration and } \\
\text { invasion, inhibits apoptosis }\end{array}$ & {$[84]$} \\
\hline InCRNA FALEC & prostate cancer & upregulation & transcriptional activation & $\begin{array}{l}\text { promotes proliferation, migration and } \\
\text { invasion }\end{array}$ & {$[85]$} \\
\hline InCRNA MALAT1 & $\begin{array}{l}\text { HeLa and HEK-293T } \\
\text { cells }\end{array}$ & upregulation & transcriptional activation & N.A. & {$[86]$} \\
\hline IncRNA ANRIL & osteosarcoma & upregulation & transcriptional activation & promotes invasion, inhibits apoptosis & {$[87]$} \\
\hline $\begin{array}{l}\text { IncRNA } \\
\text { NUTF2P3-001 }\end{array}$ & pancreatic cancer & upregulation & transcriptional activation & $\begin{array}{l}\text { promotes viability, proliferation and } \\
\text { invasion }\end{array}$ & {$[88]$} \\
\hline IncRNA HOTAIR & lung cancer & upregulation & transcriptional activation & $\begin{array}{l}\text { promotes proliferation, migration and } \\
\text { invasion }\end{array}$ & [89] \\
\hline IncRNA HOTAIR & pan-cancer & upregulation & transcriptional activation & N.A. & {$[90]$} \\
\hline IncRNA MEG3 & $\begin{array}{l}\text { MCF-7 and HEK- } \\
\text { 293T cells }\end{array}$ & upregulation & $\begin{array}{l}\text { transcriptional activation via } \\
\text { recruiting } \mathrm{CBP} / \mathrm{p} 300\end{array}$ & $\begin{array}{l}\text { promotes angiogenesis and the spheroid } \\
\text { sprouting }\end{array}$ & [91] \\
\hline IncRNA H19 & glioblastoma & upregulation & $\begin{array}{l}\text { transcriptional activation and } \\
\text { recruits SP1 }\end{array}$ & promotes migration and invasion & {$[92]$} \\
\hline InCRNA LET & $\begin{array}{l}\text { hepatocellular } \\
\text { carcinoma }\end{array}$ & downregulation & histone deacetylation & promotes migration and invasion & {$[93]$} \\
\hline
\end{tabular}


with a covalently closed continuous loop. In an experiment on breast cancer cells in a hypoxic environment, researchers found that circZNF292, circDENND4C, and circSRSF4 were upregulated after hypoxia treatment, while among these, only circDENND4C was demonstrated to be activated by the induction of HIF-1 $\alpha$ [94]. CircDENND2A was predicted to be an HRC in glioma via bioinformatic analysis. Hypoxia-induced overexpression of circDENND2A promotes the migration and invasion of glioma cells by sponging miR-625-5p [95]. In addition, more HRCs, including circRNA_403658, circDENND4C, and circRNA_0000977, have been identified to participate in cancer progression by sponging corresponding miRNAs [29, 96, 97]. Although limited research has uncovered the role of HRCs, promising functions of circRNAs in human cancers have been preliminarily established, and we believe that HRCs will be the next hotspot in the research field of hypoxia-induced cancer progression.

\section{Regulation of HIF-1a expression by ncRNAs}

To date, most HRNs are functionally characterized as having profound impact on tumorigenesis in a spectrum of cancer types. However, as a type of gene regulator, ncRNAs can participate in regulating gene expression at multiple levels. MiRNAs directly affect HIF- $1 \alpha$ expression and activity, while others may have indirect regulations. LncRNAs have diverse regulatory functions, which can modulate chromatin remodeling, transcriptional regulation, posttranscriptional processing, and translation $[98,99]$. Emerging reports have suggested the function of IncRNAs as competing endogenous RNAs (ceRNAs) for miRNAs to regulate related mRNA expression at the posttranscriptional level [100], including HIF- $1 \alpha$ mRNA. In summary, ncRNAs can mediate HIF$1 \alpha$ at the posttranscriptional level by various mechanisms, which is essential for the regulation of HIF- $1 \alpha$ expression. We summarize the regulatory mechanisms of HIF- $1 \alpha$ expression by ncRNAs in Table 4 .

\section{Posttranscriptional regulation of HIF-1a expression by ncRNAs}

MiRNAs play significant regulatory roles in eukaryotes by binding to the 3'-UTRs of corresponding mRNA transcripts, leading to silencing of the target gene at the posttranscriptional level. A large number of studies have confirmed the existence of the direct interplay between miRNAs and the 3'-UTR of HIF-1 $\alpha$ [101-121]. Although the classic mechanism is widespread and important in tumors, we do not describe it in detail in the section due to the simplicity of the interaction.

Based on the previous notion that HIF- $1 \alpha$ is a target of miR-138 [120], Cai et al. proposed that IncRNA LINC00152 functions as an miRNA sponge for miR-138 through a direct interaction to abrogate the suppressive effect of miR-138 on the expression of HIF-1 $\alpha$ [122]. Intriguingly, an almost identical role of lncRNA PVT1 acting as ceRNA for miR-199a-5p in non-small-cell lung cancer under hypoxia was later verified [123]. Additionally, the ceRNA roles of IncRNA HOTAIR [124], Linc ROR [125], lncRNA NEAT1 [126], IncRNA UCA1 [127], and lncRNA PVT1 [128] for their respective miRNAs in cancer progression have also been demonstrated. In nasopharyngeal carcinoma, regulation at the posttranscriptional level has been further extended. To be more specific, lncRNA DANCR was found to directly interact with the ILF3/ILF2 complex, and interleukin enhancer binding factor 3 (ILF3), as the most enriched DANCRbinding protein, is a double-stranded RNA-binding protein and can complex with ILF2 to stabilize mRNA and regulate gene expression, subsequently stabilizing the HIF- $1 \alpha$ mRNA and leading to nasopharyngeal carcinoma metastasis [129].

Similar to the classic mechanism by which lncRNAs participate in cancer prognosis, the most common mechanism by which circRNAs regulate biological processes is also related to the HIF- $1 \alpha$ model. This mechanism mainly involves three kinds of RNAs, including mRNAs, pseudogene transcripts and lncRNAs, but circRNAs have followed lncRNAs in becoming a novel hotspot of research on the ceRNA family. Research conducted by Chi et al. suggested that circRNA circPIP5K1A functions as a miR-600 sponge to inhibit miR-600 to disrupt the interaction at the 3'-UTR between HIF- $1 \alpha$ and miR-600 to promote HIF- $1 \alpha$ posttranscriptional expression, as well as proliferation and metastasis of non-small-cell lung cancer [130]. In addition, in hepatocellular carcinoma, circRNA_0046600 could upregulate HIF- $1 \alpha$ by sponging miR-640 to promote cancer progression [131]. CircRNAs are a novel research focus,, so no additional studies on the regulatory roles of circRNAs in HIF- $1 \alpha$ expression are currently available. Given the significant role of circRNAs in regulating target gene expression, we speculate that circRNAs should be the next focus in the field of ncRNA-mediated regulation of HIF-1 $\alpha$ expression.

\section{Transcriptional regulation of HIF-1a expression by ncRNAs}

In addition to the basic interaction between miRNAs and the 3'-UTR of HIF- $1 \alpha$, miRNA-mediated transcriptional regulation of HIF- $1 \alpha$ expression is a common mechanism in cancer progression. MiR-214 upregulates HIF- $1 \alpha$ and VEGFA with the suppression of ING4 to promote the invasion, proliferation and migration of non-small-cell lung cancer cells [132], and a possible mechanism is that ING4, which is recruited by egl-9 family hypoxia-inducible factor 1 (EGLN1), unexpectedly 
Table 4 ncRNA-mediated regulation of HIF-1a and cancer progression

\begin{tabular}{|c|c|c|c|c|}
\hline NcRNAs & Cancer types & Functions & Regulatory mechanisms & Reference \\
\hline miR-33b & osteosarcoma & inhibits proliferation and migration & post-transcriptional regulation & [101] \\
\hline miR-338-3p & hepatocellular cancer & $\begin{array}{l}\text { inhibits viability and induces apoptosis, } \\
\text { enhances the sensitivity to sorafenib }\end{array}$ & post-transcriptional regulation & [102] \\
\hline miR-138 & ovarian cancer & inhibits migration and invasion & post-transcriptional regulation & [103] \\
\hline miR-576-3p & glioma & inhibits migration and proangiogenic abilities & post-transcriptional regulation & [104] \\
\hline miR-18a-5p & lung cancer & promotes radiosensitivity & post-transcriptional regulation & [105] \\
\hline miR-3662 & hepatocellular cancer & inhibits warburg effect and growth & post-transcriptional regulation & {$[106]$} \\
\hline miR-143-5p & gallbladder cancer & inhibits EMT, proliferation, migration and invasion & post-transcriptional regulation & [107] \\
\hline miR-143 & cervical cancer & inhibits proliferation, promotes apoptosis & post-transcriptional regulation & [108] \\
\hline miR-106a/b & breast cancer & $\begin{array}{l}\text { inhibits stem-like cell specific, self-renewal and } \\
\text { sphere-forming phenotype }\end{array}$ & post-transcriptional regulation & [109] \\
\hline miR-199a-5p & melanoma & inhibits proliferation, induces arrest & post-transcriptional regulation & [110] \\
\hline miR-20b & osteosarcoma & inhibits proliferation and invasion & post-transcriptional regulation & [1111] \\
\hline miR-18b & melanoma & $\begin{array}{l}\text { inhibits proliferation, induces arrest, inhibits } \\
\text { the glycolysis }\end{array}$ & post-transcriptional regulation & [112] \\
\hline miR-622 & lung cancer & inhibits migration and invasion & post-transcriptional regulation & [113] \\
\hline miR-33a & melanoma & inhibits proliferation, invasion and metastasis & post-transcriptional regulation & [114] \\
\hline miR-338 & $\begin{array}{l}\text { nasopharyngeal } \\
\text { carcinoma }\end{array}$ & inhibits migration and proliferation & post-transcriptional regulation & [115] \\
\hline miR-20b & hepatocellular cancer & inhibits proliferation, inhibits apoptosis & post-transcriptional regulation & [116] \\
\hline miR-199a-5p & multiple myeloma & $\begin{array}{l}\text { inhibits migration, promotes adhesion, inhibits } \\
\text { endothelial cells migration }\end{array}$ & post-transcriptional regulation & [117] \\
\hline miR-199b & prostate cancer & inhibits growth, promotes death & post-transcriptional regulation & [118] \\
\hline miR-199a & hepatocellular cancer & inhibits proliferation & post-transcriptional regulation & [119] \\
\hline miR-138 & renal cancer & promotes apoptosis, inhibits migration & post-transcriptional regulation & [120] \\
\hline miR-22 & colon cancer & inhibits endothelial cell growth and invasion & post-transcriptional regulation & [121] \\
\hline $\begin{array}{l}\text { InCRNA } \\
\text { LINC00152 }\end{array}$ & gallbladder cancer & promotes migration, invasion and EMT & post-transcriptional regulation & [122] \\
\hline IncRNA PVT1 & lung cancer & promotes viability and proliferation & post-transcriptional regulation & [123] \\
\hline InCRNA HOTAIR & renal cancer & $\begin{array}{l}\text { promotes proliferation, migration and EMT, } \\
\text { inhibits apoptosis }\end{array}$ & post-transcriptional regulation & [124] \\
\hline IncRNA ROR & hepatocellular cancer & promotes viability & post-transcriptional regulation & [125] \\
\hline IncRNA NEAT1 & osteosarcoma & promotes proliferation and invasion & post-transcriptional regulation & [126] \\
\hline IncRNA UCA1 & $\begin{array}{l}\text { acute myelocytic } \\
\text { leukemia }\end{array}$ & promotes glycolysis and chemoresistance & post-transcriptional regulation & [127] \\
\hline IncRNA PVT1 & gastric cancer & promotes proliferation and invasion & post-transcriptional regulation & [128] \\
\hline InCRNA DANCR & $\begin{array}{l}\text { nasopharyngeal } \\
\text { carcinoma }\end{array}$ & promotes invasion and metastasis & $\begin{array}{l}\text { post-transcriptional activation } \\
\text { via ILF3/ ILF2 }\end{array}$ & [129] \\
\hline circPIP5K1A & lung cancer & promotes proliferation and metastasis & post-transcriptional regulation & [130] \\
\hline circRNA_0046600 & hepatocellular carcinoma & promotes migration & post-transcriptional regulation & [131] \\
\hline miR-214 & lung cancer & promotes invasion, proliferation and migration & $\begin{array}{l}\text { transcriptional activation via } \\
\text { ING4 }\end{array}$ & [132] \\
\hline miR-206 & lung cancer & $\begin{array}{l}\text { inhibits proliferation and angiogenesis, promotes } \\
\text { apoptosis }\end{array}$ & $\begin{array}{l}\text { transcriptional inhibition via } \\
\text { 14-3-3Z/STAT3 axis }\end{array}$ & [133] \\
\hline miR-675-5p & glioma & promotes angiogenesis & stabilize the mRNA via HuR & [134] \\
\hline IncRNA CPS1-IT1 & hepatocellular cancer & inhibits EMT, proliferation, migration and invasion & $\begin{array}{l}\text { transcriptional inhibition via } \\
\text { Hsp90 }\end{array}$ & [135] \\
\hline IncRNA PVT1 & gastric cancer & promotes survival, inhibits apoptosis & $\begin{array}{l}\text { transcriptional activation via } \\
\text { mTOR }\end{array}$ & [136] \\
\hline
\end{tabular}


Table 4 ncRNA-mediated regulation of HIF-1a and cancer progression (Continued)

\begin{tabular}{|c|c|c|c|c|}
\hline NCRNAs & Cancer types & Functions & Regulatory mechanisms & Reference \\
\hline miR-128 & prostate cancer & inhibits growth and metabolism & $\begin{array}{l}\text { translational inhibition via } \\
\text { RPS6KB1 }\end{array}$ & [137] \\
\hline IncRNA MEG3 & lung cancer & inhibits malignant transformation & $\begin{array}{l}\text { translational inhibition via Akt/ } \\
\text { p70S6K/S6 aixs }\end{array}$ & [138] \\
\hline InCRNA UBE2CP3 & hepatocellular cancer & promotes proliferation, migration and angiogenesis & $\begin{array}{l}\text { translational activation via ERK } \\
\text { p70S6K aixs }\end{array}$ & [139] \\
\hline multiple miRNAs & lung cancer & promotes angiogenesis & $\begin{array}{l}\text { post-translational activation via } \\
\text { FIH1 }\end{array}$ & [140] \\
\hline miR-135b & $\begin{array}{l}\text { head and neck squamous } \\
\text { cell carcinoma }\end{array}$ & $\begin{array}{l}\text { promotes proliferation, migration, colony formation and } \\
\text { angiogenesis }\end{array}$ & $\begin{array}{l}\text { post-translational activation via } \\
\mathrm{FlH} 1\end{array}$ & [141] \\
\hline miR-182 & lung cancer & promotes glucose metabolism and proliferation & $\begin{array}{l}\text { post-translational activation via } \\
\mathrm{FIH1}\end{array}$ & [142] \\
\hline miR-31 & colorectal cancer & promotes proliferation, migration and invasion & $\begin{array}{l}\text { post-translational activation via } \\
\text { FIH1 }\end{array}$ & [143] \\
\hline miR-592 & hepatocellular carcinoma & inhibits glycolytic metabolism and proliferation & $\begin{array}{l}\text { post-translational inhibition via } \\
\text { WSB1 }\end{array}$ & [144] \\
\hline miR-543 & osteosarcoma & promotes glycolytic metabolism and proliferation & $\begin{array}{l}\text { post-translational activation via } \\
\text { PRMT9 }\end{array}$ & [145] \\
\hline miR-183 & glioma & N.A. & $\begin{array}{l}\text { post-translational activation via } \\
\text { IDH2/a-KG axis }\end{array}$ & [146] \\
\hline miR-23b & glioma & promotes proliferation and migration, inhibits apoptosis & $\begin{array}{l}\text { post-translational activation via } \\
\text { VHL }\end{array}$ & [147] \\
\hline miR-145 & colorectal cancer & inhibits proliferation, migration and invasion & $\begin{array}{l}\text { post-translational inhibition via } \\
\text { Akt/ERK axis }\end{array}$ & [148] \\
\hline miR-30e & breast cancer & inhibits proliferation, migration and invasion & $\begin{array}{l}\text { post-translational inhibition via } \\
\text { IIRS1/Akt/ERK axis }\end{array}$ & [149] \\
\hline miR-26a & hepatocellular cancer & inhibits angiogenesis & $\begin{array}{l}\text { post-translational inhibition via } \\
\text { PIK3C2a/Akt axis }\end{array}$ & [150] \\
\hline miR-99a & breast cancer & inhibits migration, invasion, sphere formation & $\begin{array}{l}\text { post-translational inhibition via } \\
\text { mTOR signals }\end{array}$ & [151] \\
\hline $\begin{array}{l}\text { IncRNA } \\
\text { ENST00000480739 }\end{array}$ & pancreatic cancer & inhibits invasion & $\begin{array}{l}\text { post-translational inhibition via } \\
\text { OS9 }\end{array}$ & [152] \\
\hline miR-22 & $\begin{array}{l}\text { chronic myelogenous } \\
\text { leukemia }\end{array}$ & enhances the sensitivity to imatinib & $\begin{array}{l}\text { block HIF-1a nuclear transfer via } \\
\text { IPO7 }\end{array}$ & [153] \\
\hline IncRNA H19 & multiple myelom & promotes hypoxia-induced adhesion on the stroma & $\begin{array}{l}\text { promotes HIF-1a nuclear } \\
\text { translocation }\end{array}$ & [154] \\
\hline IncRNA MIR31HG & oral cancer & promotes proliferation, migration and invasion & $\begin{array}{l}\text { facilitates the recruitment of } \\
\text { HIF-1 complex }\end{array}$ & [155] \\
\hline $\begin{array}{l}\text { IncRNA NDRG1- } \\
\text { OT1 }\end{array}$ & breast cancer & N.A. & $\begin{array}{l}\text { acts as a scaffold for recruiting } \\
\text { HIF-1a }\end{array}$ & [156] \\
\hline
\end{tabular}

has no effect on HIF-1 $\alpha$ degeneration but acts as an adapter protein to recruit transcriptional repressors to regulate HIF activity [157]. MiR-206 can attenuate the growth and angiogenesis of non-small-cell lung cancer cells through the 14-3-3z/STAT3/HIF-1 $\alpha$ /VEGF pathway. In particular, 14-3-3 $\zeta$ binds to p-STAT3 (Ser727) and increases its activation. Knockdown of STAT3 blocks the 14-3-3 -induced increase in HIF-1 $\alpha$ mRNA expression and attenuates the 14-3-3 $\zeta$-induced binding of HIF- $1 \alpha$ to the VEGF promoter [133]. In addition, Dico et al. reported that miR-675-5p interacts with the RNA binding protein $\mathrm{HuR}$ to stabilize the mRNA of
HIF-1 $\alpha$, along with its additional inhibitory effect on VHL [134].

Moreover, at the transcription level of HIF- $1 \alpha$ expression, experimental evidence of lncRNA-mediated regulation already exists. Wang et al. suggested that lncRNA CPS1-IT1 could serve as an Hsp90 cochaperone, and this interaction in turn reduces the binding affinity between Hsp90 and HIF-1 $\alpha$, leading to transcriptional inactivation of HIF-1 $\alpha$ and diminished EMT of hepatocellular carcinoma cells [135]. In addition, the lncRNA-mediated regulation of the mTOR/HIF-1 $\alpha / \mathrm{P}$-gp signaling pathway marked by increased HIF-1a mRNA 
levels in gastric cancer cells might also suggest the alteration of HIF- $1 \alpha$ transcriptional activity [136]. Although the function of lncRNAs as transcriptional regulators has been widely explored, the mechanisms underlying these functions remain poorly understood and require further investigation.

\section{Translational regulation of HIF-1a expression by ncRNAs}

MiR-128, which is regulated by snail family zinc finger 1 (SNAIL) transcriptionally, in turn modulates the expression of ribosomal protein S6 kinase, polypeptide 1 (RPS6KB1), also known as p70S6K, and afterwards disrupts downstream HIF-1 $\alpha$ at the translational level and consequently suppresses pyruvate kinase 2 (PKM2) expression to inhibit the growth and metabolism of prostate cancer cells [137], which expands the interplay between HIF- $1 \alpha$ and miRNA at the translational level.

As for the translational activity of HIF- $1 \alpha$, lncRNA MEG3 was found to be decreased after nickel exposure, which triggers downstream c-Jun/ PH domain and leucine rich repeat protein phosphatase 1 (PHLPP1) to activate the Akt/p70S6K/S6 axis. Enhanced phosphorylation at Ser235/236 of the 40 S ribosomal protein S6 therefore boosts HIF-1 $\alpha$ translation in the nickel-induced malignant transformation of human bronchial epithelial cells [138]. In hepatocellular carcinoma cells, overexpressed lncRNA UBE2CP3 enhances human umbilical vein endothelial cell proliferation, migration and angiogenesis, which is attributed to the ERK/p70S6K/HIF-1 $\alpha$ / VEGFA signaling axis activated by lncRNA expression deviating from normal status [139]. Distinctly, lncRNAs are defined as ncRNAs without translational function. However, during HIF- $1 \alpha$ translation, IncRNAs play indispensable roles.

\section{Posttranslational regulation of HIF-1a expression by ncRNAs}

Complexes formed between HIF the coactivators CBP/ p300 are essential for HIF transcriptional activation. FIH1, which blocks the interaction between HIF-1 $\alpha$ and $\mathrm{CBP} / \mathrm{p} 300$, is validated to be downregulated because of a corresponding miRNA deficiency in tumors, consequently suppressing the tumor hypoxia response and angiogenesis by suppressing HIF-1 $\alpha$ transcription and VEGF production [140]. Similar mechanisms of miR135b, miR-182, and miR-31 have been confirmed in head and neck squamous cell carcinoma [141], nonsmall-cell lung cancer [142] and colorectal cancer [143], respectively.

The stability of HIF- $1 \alpha$ is a critical factor in its action on relevant gene expression, and WD repeat and SOCS box containing 1 (WSB1) has been reported to enhance the HIF- $1 \alpha$ protein stability derived from the abnormally low expression of miR-592 in hepatocellular carcinoma cells with enhanced glycolysis and proliferation [144]. In osteosarcoma cells, which have a high energy demand but low ATP-generating efficiency, increasing miR-543 targets the 3'-UTR of protein arginine methyltransferase 9 (PRMT9) to decrease PRMT9-induced HIF-1 $\alpha$ instability; thereafter, elevated HIF- $1 \alpha$ boosts glycolysis and proliferation of osteosarcoma cells [145]. As an indispensable molecule in the degradation of HIF- $1 \alpha$, the role of PHD in HIF- $1 \alpha$ stabilization should not be ignored. Indeed, Tanaka et al. indicated that upregulated miR-183 in glioma was able to inhibit isocitrate dehydrogenase 2 (IDH2) levels, which elevated HIF- $1 \alpha$ levels by reducing the cellular levels of $\alpha$ KG, a substrate of PHD [146]. In glioma, the targeted inhibitory effect of increasing miR-23b on VHL unsurprisingly activates HIF-1 $\alpha$ /VEGF signaling to promote tumor progression [147].

Proteasomal degradation is often regulated by phosphorylation [158], and blocked activation of the Akt and ERK1/2 pathways caused by miR-145-mediated N-RAS and insulin receptor substrate 1 (IRS1) expression inhibition was confirmed to suppress the expression of HIF$1 \alpha$ and downstream VEGF in restricted colorectal cancer growth, which is speculated to depend on its interference with the normal HIF- $1 \alpha$ protein degradation process [148]; in addition, almost the same signaling initiated by miR-30e can be seen in breast cancer [149]. Analogously, the PIK3C2 $\alpha /$ AKT/HIF-1 $\alpha /$ VEGFA pathway regulated by miR-26a plays a role in inhibiting angiogenesis in hepatocellular carcinoma [150]. Because of its important role in the PI3K/Akt/mTOR signaling pathway [159], mTOR and downstream HIF-1 $\alpha$ have been experimentally suggested to be inhibited by miR99a, which reverses the breast cancer stem cell malignant phenotype [151].

LncRNAs also play critical roles in the posttranslational regulation of HIF- $1 \alpha$ expression. Osteosarcoma amplified 9 (OS9) has an overall effect on the degradation of HIF- $1 \alpha$, including hydroxylation, VHL binding, and proteasomal degradation, by interacting with both HIF- $1 \alpha$ and PHDs [160], and lncRNA ENST00000480739 contributes to metastasis and progression of pancreatic ductal adenocarcinoma by targeting and upregulating HIF-1 $\alpha$ [152]. Whether other forms of IncRNA-related posttranslational regulation are essential for HIF- $1 \alpha$ needs to be further explored.

\section{Nuclear transfer of HIF-1a mediated by ncRNAs}

The nuclear transfer of HIF- $1 \alpha$ is also affected by miRNAs. Importin 7 (IPO7) is a mediator specifically related to HIF-1 $\alpha$ nuclear translocation [161], while in chronic myelogenous leukemia cells under curcumin treatment, there is a curcumin-induced downregulation of IPO7 expression caused by miR-22 activation, which further elicits blocked cytoplasm-to-nucleus shuttling of HIF-1 $\alpha$ to restrain the glycolytic enzyme profile [153]. 
Similar to miRNAs, lncRNA H19 has been confirmed to positively participate in HIF- $1 \alpha$ nuclear translocation to drive multiple myeloma cell dissemination, although the specific molecules responsible for this procedure are unknown [154]. As a transcription factor, HIF-1 $\alpha$ plays an essential role in the nucleus. Thus, the regulation of HIF- $1 \alpha$ nuclear transfer by ncRNAs is a promising regulatory mechanism to block the oncogenic function of HIF- $1 \alpha$ in cancer progression.

\section{Regulation of HIF-1a activity via scaffolding by ncRNAs}

The direct interaction between HIF- $1 \alpha$ and lncRNAs is not confined to the 3'-UTR. Shih et al. have demonstrated an extremely important role of IncRNA MIR31HG, which acts as a co-activator and complexes with HIF- $1 \alpha$ to facilitate the recruitment of the HIF-1 complex, augmenting the HIF-1 transcriptional network essential for oral cancer progression and leading to metabolic reprogramming, increased sphere-forming ability and metastasis [155]. However, IncRNA NDRG1OT1 was reported to act as a scaffold for recruiting HIF$1 \alpha$ via its third-quarter fragment, rather than whole molecule, to increase the expression of the downstream gene N-myc downstream regulated gene 1 (NDRG1) in breast cancer cells under hypoxia, along with the different effects of the remaining fragments on the same target gene [156].

\section{Feedback loops between HIF-1a and ncRNAs}

In addition to the unidirectional regulation pattern, emerging studies have found that there are direct and indirect feedback loops between HIF- $1 \alpha$ and miRNAs, which are much more complicated than simple one-way effects. Generally, the formation of these feedback loops makes the posttranscriptional regulation between HIF$1 \alpha$ and miRNA more diverse than that of the original linear structure.

\section{Positive feedback loops between HIF-1 $a$ and ncRNAs Positive feedback loops between HIF-1a and miRNAs} Joshi et al. revealed that based on the mutual inhibitory relationship in the HIF-1 $\alpha$-DNM2 and HIF- $1 \alpha-$ miR-199a interaction, dynamin 2 (DNM2), HIF-1 $\alpha$ and miR-199a, which arises from the opposite strand of the DNM2 gene, are integrated into a feedback loop, which increases both the posttranscriptional level and protein stability of HIF-1 $\alpha$ to promote ovarian cancer metastasis [162], and reciprocal suppression between miR-20b and HIF- $1 \alpha$ at the transcriptional and posttranscriptional levels also plays a role in fine-tuning the adaptation of tumor cells to different oxygen concentrations [163].

Given the decreased expression of miR-126 observed in the tumors of renal cell carcinoma patients who experienced metastasis [164] or recurrence [165], the positive feedback circuit featuring tumorigenic miR-126 deactivation, increased expression of solute carrier family 7 , member 5 (SLC7A5) and SEPRINE1, and stimulated mTOR-dependent HIF $1 / 2 \alpha$ translation has been confirmed to advance metastasis and therapeutic resistance in clear cell renal cell cancer [166], which also enriches the understanding of the effects of HIF- $1 \alpha$ translation in the feedback pathway.

The stabilization of HIF- $1 \alpha$ is also precisely regulated in various molecular processes. Puisse'gur et al. described in detail that in A549 lung cancer cells, miR210 is upregulated by hypoxia-induced HIF- $1 \alpha$; afterward, increased miR-210 represses the electron transport chain via succinate dehydrogenase complex, subunit D (SDHD), and consequent accumulation of succinate inhibits PHD to stabilize HIF- $1 \alpha$, thus forming a positiveautoregulatory loop [167]. Based on this feedback enhancement mechanism, the researchers later confirmed that this circular HIF- $1 \alpha /$ miR-210 interaction decreases the mortality rate and promotes the radioresistant phenotype of non-small-cell lung carcinoma cell lines [168]. A similar oncogenic hypoxic circuit, in which the role of SDHD is replaced by glycerol-3-phosphate dehydrogenase 1-like (GPD1L), has been shown to be involved in the apoptosis of triple-negative breast cancer cells [169]. Irreversible activation of the HIF-1 $\alpha$-related pathway via stimulation by the initial activation of HIF$1 \alpha$ due to hypoxia and PTEN/PI3K/Akt activation, the HIF-1 $\alpha$-induced overexpression of miR-182, and the resultant limited PHD2 and FIH1 expression due to miR-182 overexpression eventually results in HIF- $1 \alpha$ protein accumulation as well, facilitating angiogenesis and tumor growth in prostate cancer [170]. To complicate matters further, there are two positive feedback loops coexisting in multidrug-resistant hepatocellular cancer cells, namely, HIF- $1 \alpha / \mathrm{miR}-183 / \mathrm{IDH} 2 / \mathrm{HIF}-1 \alpha$ and HIF- $1 \alpha / \mathrm{miR}-183 /$ SOCS6/p-STAT3/HIF-1 $\alpha$, which may affect HIF- $1 \alpha$ at the protein stability level [171].

\section{Positive feedback loop between HIF-1a and IncRNA}

The feedback loop between HIF- $1 \alpha$ and lncRNA is also of great concern. Given that lncRNA MALAT1 enhances the disassociation of VHL from HIF-1 $\alpha$ to result in the accumulation of HIF- $1 \alpha$ and the Warburg effect in human hepatic L-02 cells under arsenite exposure [172], Ikeda et al. further revealed that HIF- $1 \alpha$ drives a positive feedback loop composed of HIF-1 $\alpha$, KDM3A and lncRNA MALAT1, where the HIF-1 $\alpha$-inducible histone modulator KDM3A promotes IncRNA MALAT1 transcription via histone demethylation at the lncRNA MALAT1 promoter, and the resulting increase in lncRNA MALAT1 in turn accelerates the stabilization of HIF- $1 \alpha$ to contribute to glycolytic activation of multiple myeloma under a hypoxic microenvironment [173]. 
HIF- $1 \alpha$ translation is also tightly regulated by a feedback loop. Inspired by the function of mTOR to selectively regulate translation of the HIF- $1 \alpha$ mRNA transcript [174], as well as the activation effect of lncRNA MALAT1 on mTOR [175], Zhang et al. envisioned a MALAT1/mTOR/HIF-1 $\alpha$ loop-mediated increase in pro-angiogenic factors in the angiogenesis process of osteosarcoma [176]. The direct interaction between HIF- $1 \alpha$ and HREs in lncRNA DARS-AS1 is capable of upregulating the expression of this lncRNA, which resorts to downstream RBM39/mTOR signaling to continuously stimulate the translation of HIF-1 $\alpha$, hence jointly promoting myeloma malignancy [177].

The altered stability of HIF- $1 \alpha$ is definitely another important output of the dynamic feedback loop. For example, in previous research on the Warburg effect, Yang et al. proclaimed that transcriptionally upregulated lincRNA-p21 (induced by HIF-1 $\alpha$ ) is able to bind HIF$1 \alpha$ and VHL, therefore blocking the VHL-HIF- $1 \alpha$ interaction to elicit HIF-1a accumulation for augmented glycolysis [178]. In experiments on aerobic glycolysis in breast cancer cells, Chen et al. found that PHD2, rather than VHL, complexes with the special RNA stem-loop structure of IncRNA HISLA derived from the extracellular vesicle transmission of tumor-associated macrophages, which interferes with its own binding to HIF- $1 \alpha$ and prevents HIF- $1 \alpha$ from being hydroxylated and degraded. The resulting enhancement of glycolysis and accumulation of lactate caused by HIF- $1 \alpha$ activation stimulates IncRNA HISLA transcription in macrophages via ERK/ELK1 signaling in turn [179].

\section{Negative feedback loop between HIF-1 $a$ and ncRNA}

In addition to the positive feedback loop that causes continuous activation of pathway components, a negative feedback loop between HIF- $1 \alpha$ and ncRNAs leading to the restriction of molecular members has also been confirmed by some researchers. In human umbilical vein endothelial cells, there is a negative regulatory loop containing miR-439 and HIF- $1 \alpha$ in which HIF- $1 \alpha$ induces miR-439 to bind to and destabilize HIF- $1 \alpha$ mRNA, hence reducing the activity of HIF- $1 \alpha$ in turn. Moreover, confirmation of this mechanism in HeLa cells further exhibited its significance in cancer therapeutics [180]. Similarly, based on this negative loop, in pancreatic cancer, HIF- $1 \alpha$-induced miR-646 expression was shown to target migration and invasion inhibitory protein (MIIP) to inhibit the deacetylation ability of HDAC6, which eventually promoted the acetylation and proteasomal degradation of HIF-1 $\alpha$ [181].

Collectively, it seems quite feasible that ncRNAs, HIF$1 \alpha$ and other co-operators would eventually intertwine to form mutually reciprocal feedback loops in both positive and negative manners. We summarize these reciprocal feedback loops in Fig. 2. In these loops, any alteration in the expression level of any member would disturb the overall balance of the network, resulting in a shift to transcriptional reprogramming, posttranscriptional regulation or translational stability.

\section{Perspectives on HIF-1a and ncRNAs in clinical practice}

HRNs as potential biomarkers in diagnosis and prognostic evaluation

Several kinds of HRNs have shown unique value in the diagnosis of various tumors. In pancreatic cancer, plasma profiling of four miRNAs, including hypoxiasensitive miR-210, and determination of their sensitivity and specificity values promises to generate feasible blood-based biomarkers for the early detection of pancreatic cancer [182], while the significantly increased expression of miR-107 seen in both tumor tissues and serum and its correlation with HIF-1 $\alpha$ expression suggest the practicality of using miR-107 as a biomarker for the detection of gastric cancer and tumor hypoxia [64]. In colorectal carcinoma, circulating miR-210, miR-21 and miR-126 present high value as noninvasive markers for early diagnosis, screening, and prognosis [183].

HRNs are of great significance in evaluating the prognosis of tumors. In pancreatic cancer, the expression of miR-646 [181] and miR-548 [67] is correlated with clinicopathological indicators such as TNM stage and overall survival (OS), and hypoxia-induced lncRNA NUTF2P3-001 overexpression also indicates advanced TNM stage and shorter survival time of patients [88]. Both Low expression of miR-592 [144] and high expression of miR-130b [184] can bring about poorer OS in hepatocellular carcinoma patients. For gastric cancer, it has been demonstrated that miR-421 regulated by HIF- $1 \alpha$ not only causes longer OS, but also can shorten the time to relapse of patients [185], and lncRNA BC005927 induced by hypoxia is also frequently upregulated in gastric cancer samples, showing adverse effects on a series of prognostic parameters, such as TNM stage, lymph node metastasis, and survival time [81]. Not surprisingly, scholars have revealed that aberrant expression of lncRNA H19 [92] and miR-215 [186] in glioblastoma confers a poor prognosis for patients. With regard to triplenegative breast cancers, a type of breast cancer with poor prognosis, patients with relatively low expression of miR210 fortunately experienced significantly better disease-free and overall survival than those with high expression of miR-210 in a study in Japanese patients [187]. In addition, a strong correlation between high IncRNA EFNA3 expression and shorter metastasis-free survival was found in breast cancer patients [188], undoubtedly enriching the prognostic value of lncRNAs in this prevalent cancer. Innovative extraction and identification of circulating exosomal miR-21 from the serum of patients with oral squamous 


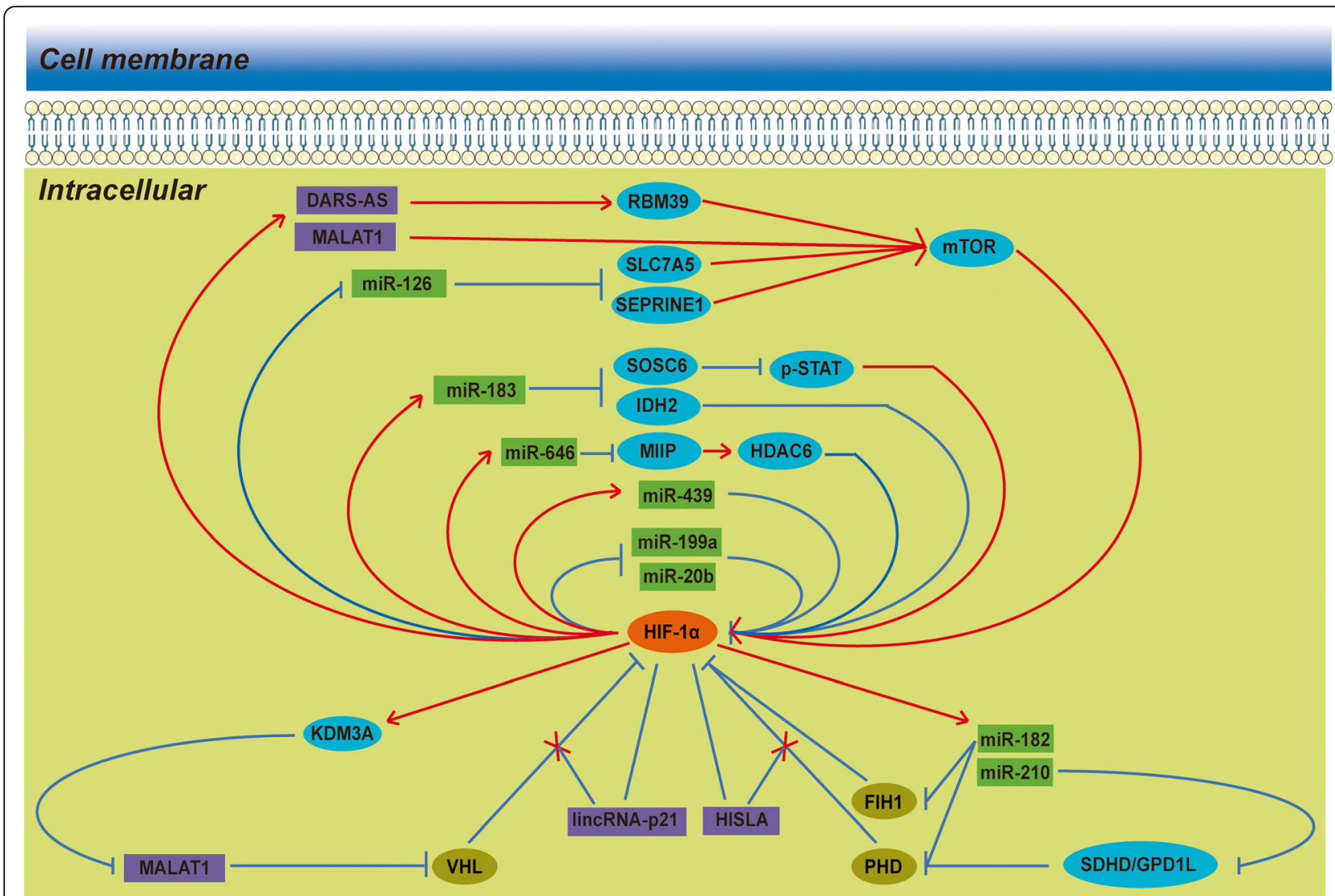

Fig. 2 Reciprocal feedback loops between HIF-1a and ncRNAs. In addition to a unidirectional regulation pattern, there are several direct or indirect feedback loops between HIF-1a and ncRNAs. It seems quite feasible that the ncRNAs, HIF-1a and other co-operators would eventually intertwine to form mutually reciprocal feedback loops in both positive and negative manners. In addition to common feedback loops, lincRNAp21 and HISLA can block VHL- and PHD-dependent HIF-1a repression instead of directly interacting with HIF-1a and other co-operators.

cell carcinoma and its close affinity with $\mathrm{T}$ stage, lymph node metastasis, and HIF- $1 \alpha$ expression further supported its prognostic value, as well as the therapeutic value of inhibiting exosomes in the niche [63]. In addition, miR-210 overexpression was reported to play a potential prognostic role in upper tract urothelial carcinoma [189] and oropharyngeal squamous cell carcinomas [190].

In addition, the expression of circFAM120A was significantly downregulated in both hypoxic lung adenocarcinoma cells and cancer tissue from patients with lymph node metastasis, implying its potential to be a new biomarker of lung adenocarcinoma hypoxia [28]. Moreover, circRNAs lack a 5' cap and 3' ends, endowing them with more stable properties than parent linear RNAs [191]. Together with their abundant and conserved characteristics, these properties make circRNAs a remarkable candidate biomarker for neoplastic diseases.

\section{Potential clinical utility of regulatory mechanisms shared between HIF-1 $a$ and ncRNAs}

The current practical applications related to regulatory mechanisms shared between HIF- $1 \alpha$ and ncRNAs are relatively scarce but inspiring. For instance, most clear cell renal cell carcinomas are marked by the loss of VHL tumor suppressor gene function, continuous expression of HIF- $1 / 2 \alpha$, and maladjusted expression of oncogenic miRNAs. Rustum et al. found that the levels of specific biomarkers associated with drug resistance in clear cell renal cell carcinoma, such as HIFs, oncogenic miR-155 and miR-210, and VEGF, could be selectively downregulated by methylselenocysteine or seleno-L-methionine in a dose- and time-dependent manner, which conferred existing anticancer therapies with enhanced therapeutic efficacy and selectivity [192]. Similarly, the antitumor effect of a novel synthetic derivative of curcumin treatment seen in pancreatic cancer was partially attributed to its inhibition of the expression of miR-21, miR-210, and HIF- $1 \alpha$, which are aberrantly upregulated under hypoxic conditions [193]. Additionally, Isanejad et al. reported that combination hormone therapy with 5-week interval exercise training could inhibit tumor angiogenesis in a mouse model of breast cancer, and the underlying mechanism could be partially explained by the suppressive effect of this combination therapy on the 
miR-21/HIF-1 $\alpha$ signaling pathway [194]. Xu et al. suggested that targeting carcinostatic miR-338-3p/HIF-1 $\alpha$ axis was conducive to sensitizing hepatocarcinoma cells to sorafenib [102], and Bertozzi et al. found that miR17-5p and miR-155 were involved in camptothecininduced HIF- $1 \alpha$ reduction in human cancer cells due to their specific targeting of HIF-1 $\alpha$ mRNA [195].

Encouragingly, ncRNAs have been increasingly considered as potential cancer therapeutic targets owing to their tissue specificity, high expression levels and crucial roles in tumor growth and progression. To date, the development of RNA-targeting methods has provided tremendous opportunities to modulate ncRNAs for cancer therapy [196, 197]. Most excitingly, novel classes of RNA-based therapeutics show great potential to modulate ncRNA activity in diverse ways [198]. Although most ncRNA-targeted treatments remain in the early stages of development, future technical innovations will provide new opportunities, and better insights into the associations between HIF- $1 \alpha$ and ncRNAs in cancer biology will lay wide theoretical foundations for ncRNArelated targeted therapies.

\section{Conclusions}

Continuing evidence indicates that both HIF-1 $\alpha$ and ncRNAs play essential roles in human cancers. In this review, we have described the reciprocal regulation between HIF- $1 \alpha$ and ncRNAs in terms of transcription, translation, and protein stability, as well as their effects on the various biological behaviors of tumor cells. We also evaluated the prospective HRN biomarkers with potential for the diagnosis and prognosis of cancer, as well as the potential clinical applications related to the regulatory mechanisms shared between HIF- $1 \alpha$ and ncRNAs in cancer treatment. Given the large number of lncRNAs and the intense research efforts to identify and evaluate these genes, a large number of lncRNAs surely remain to be further discovered. It is certain that an improved understanding of the interplay between HIF-1 $\alpha$ and ncRNAs will provide useful insights into tumorigenicity and may lead to novel clinical applications.

\section{Abbreviations}

3'-UTR: 3'-untranslated region; BCl-2: B-cell CLL/lymphoma 2; ceRNAs: Competing endogenous RNAs; CircRNAs: Circular RNAs; CREB: CAMP responsive element binding protein 1; DNM2: Dynamin 2; EGLN1: Egl-9 family hypoxia-inducible factor 1; EMT: Epithelial-mesenchymal transition; EPHB4: EPH receptor B4; FIH1: Hypoxia-inducible factor 1, alpha subunit inhibitor; GPD1L: Glycerol-3-phosphate dehydrogenase 1-like; HDACs: Histone deacetylases; HIF-1a: Hypoxia-inducible factor-1 alpha; HOXA9: Homeobox A9; HRCs: Hypoxia-responsive circRNAs; HREs: Hypoxiaresponse elements; HRLs: Hypoxia-responsive InCRNAs; HRMs: Hypoxiaresponsive miRNAs; HRNs: Hypoxia-responsive ncRNAs; IDH2: Isocitrate dehydrogenase 2; ILF3: Interleukin enhancer binding factor 3; IPO7: Importin 7; IRS1: Insulin receptor substrate 1; KDM1B: Lysine (K)-specific demethylase 1B; IncRNAs: Long ncRNAs; MIIP: Migration and invasion inhibitory protein, OS: overall survival; miRNAs: MicroRNAs; ncRNAs: Noncoding RNAs: NDRG1: N-myc downstream regulated gene 1; OS9: Osteosarcoma amplified
9; PHDs: Prolyl hydroxylase domain enzymes; PHLPP1: PH domain and leucine rich repeat protein phosphatase 1; PKM2: Pyruvate kinase 2; primiRNAs: Primary miRNAs; PRMT9: Protein arginine methyltransferase 9; PTEN: Phosphatase and tensin homolog; PTPN1: Protein tyrosine phosphatase, non-receptor type 1; RASSF8: Ras association domain family member 8; RPS6KB1: Ribosomal protein S6 kinase, polypeptide 1;

SDHD: Succinate dehydrogenase complex, subunit D; SLC7A5: Solute carrier family 7, member 5; SNAIL: Snail family zinc finger 1; VASP: Vasodilatorstimulated phosphoprotein; VHL: Von Hippel Lindau; WSB1: WD repeat and sOCS box containing 1

\section{Acknowledgements \\ Not applicable}

\section{Authors' contributions}

$\mathrm{JM}$ and $\mathrm{CL}$ conceptualized the review. XP, HG, RX and HW wrote the manuscript. XP and JM prepared the figures and tables. JM and CL critically reviewed and edited the manuscript. All authors read and approved the final manuscript.

\section{Funding}

This work was supported by grants from the Natural Science Foundation of Jiangsu Province of China (BE2017626) and the Foundation of Wuxi Health Commission (QNRC003).

\section{Availability of data and materials}

Not applicable

Ethics approval and consent to participate

Not applicable

\section{Consent for publication}

Not applicable

\section{Competing interests}

The authors declare that they have no competing interests.

\section{Author details}

${ }^{1}$ Department of Oncology, Wuxi People's Hospital Affiliated to Nanjing Medical University, 299 Qingyang Road, Wuxi 214023, China. ${ }^{2}$ The First Clinical Medicine School, Nanjing Medical University, Nanjing 211166, China. ${ }^{3}$ Wuxi School of Medicine, Jiangnan University, Wuxi 214122, China. ${ }^{4}$ School of Basic Medical Sciences, Nanjing Medical University, Nanjing 211166, China.

Received: 30 December 2019 Accepted: 27 January 2020

Published online: 03 February 2020

\section{References}

1. Lin SC, Liao WL, Lee JC, Tsai SJ. Hypoxia-regulated gene network in drug resistance and cancer progression. Exp Biol Med (Maywood). 2014;239(7): 779-92.

2. Peitzsch C, Perrin R, Hill RP, Dubrovska A, Kurth I. Hypoxia as a biomarker for radioresistant cancer stem cells. Int J Radiat Biol. 2014;90(8):636-52.

3. Majmundar AJ, Wong WJ, Simon MC. Hypoxia-inducible factors and the response to hypoxic stress. Mol Cell. 2010;40(2):294-309.

4. Shannon AM, Bouchier-Hayes DJ, Condron CM, Toomey D. Tumour hypoxia, chemotherapeutic resistance and hypoxia-related therapies. Cancer Treat Rev. 2003:29(4):297-307.

5. Semenza GL. Intratumoral hypoxia, radiation resistance, and HIF-1. Cancer Cell. 2004;5(5):405-6.

6. Semenza GL. Targeting HIF-1 for cancer therapy. Nat Rev Cancer. 2003;3(10): 721-32.

7. Papandreou I, Cairns RA, Fontana L, Lim AL, Denko NC. HIF-1 mediates adaptation to hypoxia by actively downregulating mitochondrial oxygen consumption. Cell Metab. 2006;3(3):187-97.

8. He M, Wang QY, Yin QQ, Tang J, Lu Y, Zhou CX, et al. HIF-1alpha downregulates miR-17/20a directly targeting p21 and STAT3: a role in myeloid leukemic cell differentiation. Cell Death Differ. 2013;20(3):408-18.

9. Harris AL. Hypoxia--a key regulatory factor in tumour growth. Nat Rev Cancer. 2002;2(1):38-47. 
10. Gleadle JM. Review article: How cells sense oxygen: lessons from and for the kidney. Nephrology (Carlton). 2009;14(1):86-93.

11. McNeill LA, Hewitson KS, Claridge TD, Seibel JF, Horsfall LE, Schofield CJ. Hypoxia-inducible factor asparaginyl hydroxylase $(\mathrm{FlH}-1)$ catalyses hydroxylation at the beta-carbon of asparagine-803. Biochem J. 2002;367(Pt 3):571-5.

12. Koivunen P, Hirsila M, Gunzler V, Kivirikko Kl, Myllyharju J. Catalytic properties of the asparaginyl hydroxylase $(\mathrm{FIH})$ in the oxygen sensing pathway are distinct from those of its prolyl 4-hydroxylases. J Biol Chem. 2004;279(11):9899-904.

13. Lando D, Peet DJ, Gorman JJ, Whelan DA, Whitelaw ML, Bruick RK. FIH-1 is an asparaginyl hydroxylase enzyme that regulates the transcriptional activity of hypoxia-inducible factor. Genes Dev. 2002;16(12):1466-71.

14. Wenger RH, Stiehl DP, Camenisch G. Integration of oxygen signaling at the consensus HRE. Sci STKE. 2005:(306):re12.

15. Huang LE, Gu J, Schau M, Bunn HF. Regulation of hypoxia-inducible factor 1alpha is mediated by an O2-dependent degradation domain via the ubiquitin-proteasome pathway. Proc Natl Acad Sci U S A. 1998;95(14):7987-92.

16. Gibb EA, Brown CJ, Lam WL. The functional role of long non-coding RNA in human carcinomas. Mol Cancer. 2011;10:38.

17. Gomez-Verjan JC, Vazquez-Martinez ER, Rivero-Segura NA, Medina-Campos $\mathrm{RH}$. The RNA world of human ageing. Hum Genet. 2018;137(11-12):865-79.

18. Davalos V, Esteller M. Disruption of Long Noncoding RNAs Targets Cancer Hallmark Pathways in Lung Tumorigenesis. Cancer Res. 2019;79(12):3028-30.

19. Iyer MK, Niknafs YS, Malik R, Singhal U, Sahu A, Hosono Y, et al. The landscape of long noncoding RNAs in the human transcriptome. Nat Genet. 2015;47(3):199-208.

20. Bartonicek N, Maag JL, Dinger ME. Long noncoding RNAs in cancer: mechanisms of action and technological advancements. Mol Cancer. 2016; 15(1):43.

21. Engreitz JM, Sirokman $K$, McDonel P, Shishkin AA, Surka C, Russell $P$, et al. RNA-RNA interactions enable specific targeting of noncoding RNAs to nascent Pre-mRNAs and chromatin sites. Cell. 2014;159(1):188-99.

22. Runtsch MC, O'Neill LA. GOTcha: IncRNA-ACOD1 targets metabolism during viral infection. Cell Res. 2018;28(2):137-8.

23. Michelini F, Pitchiaya S, Vitelli V, Sharma S, Gioia U, Pessina F, et al. Damageinduced IncRNAs control the DNA damage response through interaction with DDRNAs at individual double-strand breaks. Nat Cell Biol. 2017:19(12):1400-11.

24. Semenza GL. Hypoxia-inducible factors: mediators of cancer progression and targets for cancer therapy. Trends Pharmacol Sci. 2012;33(4):207-14.

25. Semenza GL. Molecular mechanisms mediating metastasis of hypoxic breast cancer cells. Trends Mol Med. 2012;18(9):534-43.

26. Shih JW, Kung HJ. Long non-coding RNA and tumor hypoxia: new players ushered toward an old arena. J Biomed Sci. 2017;24(1):53.

27. Slemc L, Kunej T. Transcription factor HIF1A: downstream targets, associated pathways, polymorphic hypoxia response element (HRE) sites, and initiative for standardization of reporting in scientific literature. Tumour Biol. 2016; 37(11):14851-61.

28. Cheng X, Qiu J, Wang S, Yang Y, Guo M, Wang D, et al. Comprehensive circular RNA profiling identifies CircFAM120A as a new biomarker of hypoxic lung adenocarcinoma. Ann Transl Med. 2019;7(18):442.

29. Wei Y, Zhang Y, Meng Q, Cui L, Xu C. Hypoxia-induced circular RNA has circRNA_403658 promotes bladder cancer cell growth through activation of LDHA. Am J Transl Res. 2019;11(11):6838-49.

30. Choudhry H, Harris AL, Mclntyre A. The tumour hypoxia induced noncoding transcriptome. Mol Aspects Med. 2016;47-48:35-53.

31. Bandara KV, Michael MZ, Gleadle JM. MicroRNA Biogenesis in Hypoxia. Microrna. 2017;6(2):80-96.

32. Shen G, Li X, Jia YF, Piazza GA, Xi Y. Hypoxia-regulated microRNAs in human cancer. Acta Pharmacol Sin. 2013;34(3):336-41.

33. Li L, Huang K, You Y, Fu X, Hu L, Song L, et al. Hypoxia-induced miR-210 in epithelial ovarian cancer enhances cancer cell viability via promoting proliferation and inhibiting apoptosis. Int J Oncol. 2014;44(6):2111-20.

34. Yang W, Sun T, Cao J, Liu F, Tian Y, Zhu W. Downregulation of miR-210 expression inhibits proliferation, induces apoptosis and enhances radiosensitivity in hypoxic human hepatoma cells in vitro. Exp Cell Res. 2012;318(8):944-54.

35. Cui H, Seubert B, Stahl E, Dietz H, Reuning U, Moreno-Leon L, et al. Tissue inhibitor of metalloproteinases-1 induces a pro-tumourigenic increase of miR-210 in lung adenocarcinoma cells and their exosomes. Oncogene. 2015;34(28):3640-50
36. Sun Y, Xing X, Liu Q, Wang Z, Xin Y, Zhang P, et al. Hypoxia-induced autophagy reduces radiosensitivity by the HIF-1alpha/miR-210/Bcl-2 pathway in colon cancer cells. Int J Oncol. 2015;46(2):750-6.

37. Zhang Y, Yan J, Wang L, Dai H, Li N, Hu W, et al. HIF-1alpha Promotes Breast Cancer Cell MCF-7 Proliferation and Invasion Through Regulating miR-210. Cancer Biother Radiopharm. 2017;32(8):297-301.

38. Ying Q, Liang L, Guo W, Zha R, Tian Q, Huang S, et al. Hypoxia-inducible microRNA-210 augments the metastatic potential of tumor cells by targeting vacuole membrane protein 1 in hepatocellular carcinoma. Hepatology. 2011;54(6):2064-75.

39. Ren D, Yang Q, Dai Y, Guo W, Du H, Song L, et al. Oncogenic miR-210-3p promotes prostate cancer cell EMT and bone metastasis via NF-kappaB signaling pathway. Mol Cancer. 2017;16(1):117.

40. Yang W, Wei J, Guo T, Shen Y, Liu F. Knockdown of miR-210 decreases hypoxic glioma stem cells stemness and radioresistance. Exp Cell Res. 2014; 326(1):22-35.

41. Camps C, Buffa FM, Colella S, Moore J, Sotiriou C, Sheldon H, et al. hsa-miR210 Is induced by hypoxia and is an independent prognostic factor in breast cancer. Clin Cancer Res. 2008;14(5):1340-8.

42. Neal CS, Michael MZ, Rawlings LH, Van der Hoek MB, Gleadle JM. The VHLdependent regulation of microRNAs in renal cancer. BMC Med. 2010;8:64.

43. Yu P, Fan S, Huang L, Yang L, Du Y. MIR210 as a potential molecular target to block invasion and metastasis of gastric cancer. Medical hypotheses. 2015;84(3):209-12.

44. King HW, Michael MZ, Gleadle JM. Hypoxic enhancement of exosome release by breast cancer cells. BMC Cancer. 2012;12:421.

45. Tsuchiya S, Fujiwara T, Sato F, Shimada Y, Tanaka E, Sakai Y, et al. MicroRNA210 regulates cancer cell proliferation through targeting fibroblast growth factor receptor-like 1 (FGFRL1). J Biol Chem. 2011;286(1):420-8.

46. Zuo J, Wen M, Lei M, Peng X, Yang X, Liu Z. MiR-210 links hypoxia with cell proliferation regulation in human Laryngocarcinoma cancer. J Cell Biochem. 2015:116(6):1039-49.

47. Chen X, Guo J, Xi RX, Chang YW, Pan FY, Zhang XZ. MiR-210 expression reverses radioresistance of stem-like cells of oesophageal squamous cell carcinoma. World J Clin Oncol. 2014;5(5):1068-77.

48. McCormick RI, Blick C, Ragoussis J, Schoedel J, Mole DR, Young AC, et al. miR-210 is a target of hypoxia-inducible factors 1 and 2 in renal cancer, regulates ISCU and correlates with good prognosis. Br J Cancer. 2013;108(5):1133-42.

49. Nakada C, Tsukamoto Y, Matsuura K, Nguyen TL, Hijiya N, Uchida T, et al. Overexpression of miR-210, a downstream target of HIF1alpha, causes centrosome amplification in renal carcinoma cells. J Pathol. 2011;224(2):280-8.

50. Chio CC, Lin JW, Cheng HA, Chiu WT, Wang YH, Wang JJ, et al. MicroRNA210 targets antiapoptotic BCl-2 expression and mediates hypoxia-induced apoptosis of neuroblastoma cells. Arch Toxicol. 2013;87(3):459-68.

51. Lu L, Xu H, Yang P, Xue J, Chen C, Sun Q, et al. Involvement of HIF-1alpharegulated miR-21, acting via the Akt/NF-kappaB pathway, in malignant transformation of HBE cells induced by cigarette smoke extract. Toxicol Lett. 2018;289:14-21.

52. Seok JK, Lee SH, Kim MJ, Lee YM. MicroRNA-382 induced by HIF-1alpha is an angiogenic miR targeting the tumor suppressor phosphatase and tensin homolog. Nucleic Acids Res. 2014;42(12):8062-72.

53. He C, Wang L, Zhang J, Xu H. Hypoxia-inducible microRNA-224 promotes the cell growth, migration and invasion by directly targeting RASSF8 in gastric cancer. Mol Cancer. 2017;16(1):35.

54. Hu J, Sun T, Wang H, Chen Z, Wang S, Yuan L, et al. MiR-215 Is Induced Post-transcriptionally via HIF-Drosha Complex and Mediates GliomaInitiating Cell Adaptation to Hypoxia by Targeting KDM1B. Cancer Cell. 2016;29(1):49-60.

55. Mao G, Liu Y, Fang $X$, Liu $Y$, Fang $L$, Lin $L$, et al. Tumor-derived microRNA494 promotes angiogenesis in non-small cell lung cancer. Angiogenesis. 2015;18(3):373-82.

56. Blick C, Ramachandran A, McCormick R, Wigfield S, Cranston D, Catto J, et al. Identification of a hypoxia-regulated miRNA signature in bladder cancer and a role for miR-145 in hypoxia-dependent apoptosis. $\mathrm{Br} J$ Cancer. 2015;113(4):634-44.

57. Nagpal N, Ahmad HM, Chameettachal S, Sundar D, Ghosh S, Kulshreshtha R. HIF-inducible miR-191 promotes migration in breast cancer through complex regulation of TGFbeta-signaling in hypoxic microenvironment. Sci Rep. 2015;5:9650. 
58. Zhao Q, Li Y, Tan BB, Fan LQ, Yang PG, Tian Y. HIF-1alpha Induces Multidrug Resistance in Gastric Cancer Cells by Inducing MiR-27a. PLoS One. 2015; 10(8):e0132746.

59. Zhang D, Shi Z, Li M, Mi J. Hypoxia-induced miR-424 decreases tumor sensitivity to chemotherapy by inhibiting apoptosis. Cell Death Dis. 2014;5:e1301.

60. Mace TA, Collins AL, Wojcik SE, Croce CM, Lesinski GB, Bloomston M. Hypoxia induces the overexpression of microRNA-21 in pancreatic cancer cells. J Surg Res. 2013;184(2):855-60.

61. Song Z, Ren H, Gao S, Zhao T, Wang X, Zhang S, et al. The hypoxiainducible factor-1 regulates the microRNA185 expression through binding to hypoxia response elements sequence 2. Med Oncol. 2013;30(4):756

62. Lu Y, Li Y, Wang Z, Xie S, Wang Q, Lei X, et al. Downregulation of RGMA by HIF-1A/miR-210-3p axis promotes cell proliferation in oral squamous cell carcinoma. Biomed Pharmacother. 2019;112:108608.

63. Li L, Li C, Wang S, Wang Z, Jiang J, Wang W, et al. Exosomes Derived from Hypoxic Oral Squamous Cell Carcinoma Cells Deliver miR-21 to Normoxic Cells to Elicit a Prometastatic Phenotype. Cancer Res. 2016;76(7):1770-80.

64. Ayremlou N, Mozdarani H, Mowla SJ, Delavari A. Increased levels of serum and tissue miR-107 in human gastric cancer: Correlation with tumor hypoxia. Cancer Biomark. 2015;15(6):851-60.

65. Liu Z, Wang Y, Dou C, Xu M, Sun L, Wang L, et al. Hypoxia-induced upregulation of VASP promotes invasiveness and metastasis of hepatocellular carcinoma. Theranostics. 2018;8(17):4649-63.

66. Li H, Rokavec M, Jiang L, Horst D, Hermeking H. Antagonistic Effects of p53 and HIF1A on microRNA-34a Regulation of PPP1R11 and STAT3 and Hypoxia-induced Epithelial to Mesenchymal Transition in Colorectal Cancer Cells. Gastroenterology. 2017;153(2):505-20.

67. Zhu S, He C, Deng S, Li X, Cui S, Zeng Z, et al. MiR-548an, Transcriptionally Downregulated by HIF1alpha/HDAC1, Suppresses Tumorigenesis of Pancreatic Cancer by Targeting Vimentin Expression. Mol Cancer Ther. 2016; 15(9):2209-19.

68. Lai HH, Li JN, Wang MY, Huang HY, Croce CM, Sun HL, et al. HIF-1alpha promotes autophagic proteolysis of Dicer and enhances tumor metastasis. J Clin Invest. 2018;128(2):625-43.

69. Guo XF, Wang AY, Liu J. HIFs-MiR-33a-Twsit1 axis can regulate invasiveness of hepatocellular cancer cells. Eur Rev Med Pharmacol Sci. 2016;20(14):3011-6.

70. Gandellini P, Giannoni E, Casamichele A, Taddei ML, Callari M, Piovan C, et al. MiR-205 hinders the malignant interplay between prostate cancer cells and associated fibroblasts. Antioxid Redox Signal. 2014;20(7):1045-59.

71. Cao P, Deng Z, Wan M, Huang W, Cramer SD, Xu J, et al. MicroRNA-101 negatively regulates Ezh2 and its expression is modulated by androgen receptor and HIF-1alpha/HIF-1beta. Mol Cancer. 2010;9:108.

72. Huang S, Qi P, Zhang T, Li F, He X. The HIF1alpha/miR2243p/ATG5 axis affects cell mobility and chemosensitivity by regulating hypoxiainduced protective autophagy in glioblastoma and astrocytoma. Oncol Rep. 2019; 41(3):1759-68.

73. Jing XG, Chen TF, Huang C, Wang H, An L, Cheng Z, et al. MiR-15a expression analysis in non-small cell lung cancer A549 cells under local hypoxia microenvironment. Eur Rev Med Pharmacol Sci. 2017;21(9):2069-74.

74. Chan SY, Loscalzo J. MicroRNA-210: a unique and pleiotropic hypoxamir. Cell Cycle. 2010;9(6):1072-83.

75. Corn PG. Hypoxic regulation of miR-210: shrinking targets expand HIF-1's influence. Cancer Biol Ther. 2008;7(2):265-7.

76. Huang $X, Z$ Zuo J. Emerging roles of miR-210 and other non-coding RNAs in the hypoxic response. Acta Biochim Biophys Sin (Shanghai). 2014;46(3):220-32.

77. Liu Y, Nie H, Zhang K, Ma D, Yang G, Zheng Z, et al. A feedback regulatory loop between HIF-1alpha and miR-21 in response to hypoxia in cardiomyocytes. FEBS Lett. 2014;588(17):3137-46.

78. Kim YK, Kim B, Kim VN. Re-evaluation of the roles of DROSHA, Export in 5, and DICER in microRNA biogenesis. Proc Natl Acad Sci U S A. 2016;113(13): E1881-9.

79. Michlewski G, Caceres JF. Post-transcriptional control of miRNA biogenesis. RNA. 2019;25(1):1-16

80. Shen J, Xia W, Khotskaya YB, Huo L, Nakanishi K, Lim SO, et al. EGFR modulates microRNA maturation in response to hypoxia through phosphorylation of AGO2. Nature. 2013;497(7449):383-7.

81. Liu X, Wang Y, Sun L, Min J, Liu J, Chen D, et al. Long noncoding RNA BC005927 upregulates EPHB4 and promotes gastric cancer metastasis under hypoxia. Cancer Sci. 2018;109(4):988-1000.
82. Deng SJ, Chen HY, Ye Z, Deng SC, Zhu S, Zeng Z, et al. Hypoxia-induced LncRNA-BX111 promotes metastasis and progression of pancreatic cancer through regulating ZEB1 transcription. Oncogene. 2018;37(44):5811-28.

83. Li T, Xiao Y, Huang T. HIF1alphainduced upregulation of InCRNA UCA1 promotes cell growth in osteosarcoma by inactivating the PTEN/AKT signaling pathway. Oncol Rep. 2018;39(3):1072-80.

84. Xue M, Li X, Li Z, Chen W. Urothelial carcinoma associated 1 is a hypoxiainducible factor-1alpha-targeted long noncoding RNA that enhances hypoxic bladder cancer cell proliferation, migration, and invasion. Tumour Biol. 2014;35(7):6901-12.

85. Zhao R, Sun F, Bei X, Wang X, Zhu Y, Jiang C, et al. Upregulation of the long non-coding RNA FALEC promotes proliferation and migration of prostate cancer cell lines and predicts prognosis of PCa patients. Prostate. 2017;77(10):1107-17.

86. Salle-Lefort S, Miard S, Nolin MA, Boivin L, Pare ME, Debigare R, et al. Hypoxia upregulates Malat1 expression through a CaMKK/AMPK/HIF-1alpha axis. Int J Oncol. 2016;49(4):1731-6.

87. Wei X, Wang C, Ma C, Sun W, Li H, Cai Z. Long noncoding RNA ANRIL is activated by hypoxia-inducible factor-1alpha and promotes osteosarcoma cell invasion and suppresses cell apoptosis upon hypoxia. Cancer Cell Int. 2016;16:73.

88. Li X, Deng SJ, Zhu S, Jin Y, Cui SP, Chen JY, et al. Hypoxia-induced IncRNANUTF2P3-001 contributes to tumorigenesis of pancreatic cancer by derepressing the miR-3923/KRAS pathway. Oncotarget. 2016;7(5):6000-14.

89. Zhou C, Ye L, Jiang C, Bai J, Chi Y, Zhang H. Long noncoding RNA HOTAIR, a hypoxia-inducible factor-1alpha activated driver of malignancy, enhances hypoxic cancer cell proliferation, migration, and invasion in non-small cell lung cancer. Tumour Biol. 2015;36(12):9179-88.

90. Bhan A, Deb P, Shihabeddin N, Ansari KI, Brotto M, Mandal SS. Histone methylase MLL1 coordinates with HIF and regulate IncRNA HOTAIR expression under hypoxia. Gene. 2017;629:16-28.

91. Ruan W, Zhao F, Zhao S, Zhang L, Shi L, Pang T. Knockdown of long noncoding RNA MEG3 impairs VEGF-stimulated endothelial sprouting angiogenesis via modulating VEGFR2 expression in human umbilical vein endothelial cells. Gene. 2018;649:32-9.

92. Wu W, Hu Q, Nie E, Yu T, Wu Y, Zhi T, et al. Hypoxia induces H19 expression through direct and indirect Hif-1alpha activity, promoting oncogenic effects in glioblastoma. Sci Rep. 2017;7:45029.

93. Yang F, Huo XS, Yuan SX, Zhang L, Zhou WP, Wang F, et al. Repression of the long noncoding RNA-LET by histone deacetylase 3 contributes to hypoxia-mediated metastasis. Mol Cell. 2013;49(6):1083-96.

94. Liang G, Liu Z, Tan L, Su AN, Jiang WG, Gong C. HIF1alpha-associated circDENND4C Promotes Proliferation of Breast Cancer Cells in Hypoxic Environment. Anticancer Res. 2017;37(8):4337-43.

95. Su H, Zou D, Sun Y, Dai Y. Hypoxia-associated circDENND2A promotes glioma aggressiveness by sponging miR-625-5p. Cell Mol Biol Lett. 2019;24:24.

96. Ren S, Liu J, Feng Y, Li Z, He L, Li L, et al. Knockdown of circDENND4C inhibits glycolysis, migration and invasion by up-regulating miR-200b/c in breast cancer under hypoxia. J Exp Clin Cancer Res. 2019;38(1):388.

97. Ou ZL, Luo Z, Wei W, Liang S, Gao TL, Lu YB. Hypoxia-induced shedding of MICA and HIF1A-mediated immune escape of pancreatic cancer cells from NK cells: role of circ_0000977/miR-153 axis. RNA Biol. 2019;16(11):1592-603.

98. Dahariya S, Paddibhatla I, Kumar S, Raghuwanshi S, Pallepati A, Gutti RK Long non-coding RNA: Classification, biogenesis and functions in blood cells. Mol Immunol. 2019;112:82-92.

99. Fico A, Fiorenzano A, Pascale E, Patriarca EJ, Minchiotti G. Long non-coding RNA in stem cell pluripotency and lineage commitment: functions and evolutionary conservation. Cell Mol Life Sci. 2019;76(8):1459-71.

100. Sun C, Li S, Zhang F, Xi Y, Wang L, Bi Y, et al. Long non-coding RNA NEAT1 promotes non-small cell lung cancer progression through regulation of miR-377-3p-E2F3 pathway. Oncotarget. 2016;7(32):51784-814.

101. Zhou Y, Yang C, Wang K, Liu X, Liu Q. MicroRNA-33b Inhibits the Proliferation and Migration of Osteosarcoma Cells via Targeting HypoxiaInducible Factor-1alpha. Oncol Res. 2017:25(3):397-405.

102. Xu H, Zhao L, Fang Q, Sun J, Zhang S, Zhan C, et al. MiR-338-3p inhibits hepatocarcinoma cells and sensitizes these cells to sorafenib by targeting hypoxia-induced factor 1alpha. PLoS One. 2014;9(12):e115565

103. Yeh YM, Chuang CM, Chao KC, Wang LH. MicroRNA-138 suppresses ovarian cancer cell invasion and metastasis by targeting SOX4 and HIF-1alpha. Int J Cancer. 2013;133(4):867-78

104. Hu Q, Liu F, Yan T, Wu M, Ye M, Shi G, et al. MicroRNA5763p inhibits the migration and proangiogenic abilities of hypoxiatreated glioma cells through hypoxiainducible factor1alpha. Int J Mol Med. 2019;43(6):2387-97. 
105. Chen X, Wu L, Li D, Xu Y, Zhang L, Niu K, et al. Radiosensitizing effects of miR-18a-5p on lung cancer stem-like cells via downregulating both ATM and HIF-1alpha. Cancer Med. 2018;7(8):3834-47.

106. Chen Z, Zuo X, Zhang Y, Han G, Zhang L, Wu J, et al. MiR-3662 suppresses hepatocellular carcinoma growth through inhibition of HIF-1alpha-mediated Warburg effect. Cell Death Dis. 2018;9(5):549.

107. He M, Zhan M, Chen W, Xu S, Long M, Shen H, et al. MiR-143-5p Deficiency Triggers EMT and Metastasis by Targeting HIF-1alpha in Gallbladder Cancer. Cell Physiol Biochem. 2017;42(5):2078-92.

108. Zhao Y, Liu X, Lu YX. MicroRNA-143 regulates the proliferation and apoptosis of cervical cancer cells by targeting HIF-1alpha. Eur Rev Med Pharmacol Sci. 2017;21(24):5580-6.

109. Liu Y, Zhang J, Sun X, Li M. EMMPRIN Down-regulating miR-106a/b Modifies Breast Cancer Stem-like Cell Properties via Interaction with Fibroblasts Through STAT3 and HIF-1alpha. Sci Rep. 2016;6:28329.

110. Yang X, Lei S, Long J, Liu X, Wu Q. MicroRNA-199a-5p inhibits tumor proliferation in melanoma by mediating HIF-1alpha. Mol Med Rep. 2016;13(6):5241-7.

111. Liu M, Wang D, Li N. MicroRNA-20b Downregulates HIF-1alpha and Inhibits the Proliferation and Invasion of Osteosarcoma Cells. Oncol Res. 2016;23(5):257-66.

112. Chen Y, Zhang Z, Luo C, Chen Z, Zhou J. MicroRNA-18b inhibits the growth of malignant melanoma via inhibition of HIF-1alpha-mediated glycolysis. Oncol Rep. 2016;36(1):471-9.

113. Cheng CW, Chen PM, Hsieh YH, Weng CC, Chang CW, Yao CC, et al. Foxo3a-mediated overexpression of microRNA-622 suppresses tumor metastasis by repressing hypoxia-inducible factor-1alpha in ERK-responsive lung cancer. Oncotarget. 2015;6(42):44222-38.

114. Zhou J, Xu D, Xie H, Tang J, Liu R, Li J, et al. MiR-33a functions as a tumor suppressor in melanoma by targeting HIF-1alpha. Cancer Biol Ther. 2015; 16(6):846-55.

115. Shan Y, Li X, You B, Shi S, Zhang Q, You Y. MicroRNA-338 inhibits migration and proliferation by targeting hypoxia-induced factor 1alpha in nasopharyngeal carcinoma. Oncol Rep. 2015;34(4):1943-52.

116. Xue TM, Tao LD, Zhang M, Zhang J, Liu X, Chen GF, et al. Clinicopathological Significance of MicroRNA-20b Expression in Hepatocellular Carcinoma and Regulation of HIF-1alpha and VEGF Effect on Cell Biological Behaviour. Dis Markers. 2015;2015:325176.

117. Raimondi L, Amodio N, Di Martino MT, Altomare E, Leotta M, Caracciolo D, et al. Targeting of multiple myeloma-related angiogenesis by miR-199a-5p mimics: in vitro and in vivo anti-tumor activity. Oncotarget. 2014;5(10):3039-54.

118. Shang W, Chen X, Nie L, Xu M, Chen N, Zeng H, et al. MiR199b suppresses expression of hypoxia-inducible factor 1alpha (HIF-1alpha) in prostate cancer cells. Int J Mol Sci. 2013;14(4):8422-36.

119. Jia XQ, Cheng HQ, Qian X, Bian CX, Shi ZM, Zhang JP, et al. Lentivirusmediated overexpression of microRNA-199a inhibits cell proliferation of human hepatocellular carcinoma. Cell Biochem Biophys. 2012;62(1):237-44

120. Song T, Zhang X, Wang C, Wu Y, Cai W, Gao J, et al. MiR-138 suppresses expression of hypoxia-inducible factor 1alpha (HIF-1alpha) in clear cell renal cell carcinoma 786-O cells. Asian Pac J Cancer Prev. 2011;12(5):1307-11.

121. Yamakuchi M, Yagi S, Ito T, Lowenstein CJ. MicroRNA-22 regulates hypoxia signaling in colon cancer cells. PLoS One. 2011;6(5):e20291.

122. Cai $Q$, Wang Z, Wang S, Weng M, Zhou D, Li C, et al. Long non-coding RNA LINC00152 promotes gallbladder cancer metastasis and epithelial-mesenchymal transition by regulating HIF-1alpha via miR-138. Open Biol. 2017;7(1):160247.

123. Wang C, Han C, Zhang Y, Liu F. LncRNA PVT1 regulate expression of HIF1alpha via functioning as ceRNA for miR199a5p in nonsmall cell lung cancer under hypoxia. Mol Med Rep. 2018;17(1):1105-10.

124. Hong Q, Li O, Zheng W, Xiao WZ, Zhang L, Wu D, et al. LncRNA HOTAIR regulates HIF-1alpha/AXL signaling through inhibition of miR-217 in renal cell carcinoma. Cell Death Dis. 2017;8(5):e2772.

125. Takahashi K, Yan IK, Haga H, Patel T. Modulation of hypoxia-signaling pathways by extracellular linc-RoR. J Cell Sci. 2014;127(Pt 7):1585-94.

126. Tan H, Zhao L. IncRNA nuclear-enriched abundant transcript 1 promotes cell proliferation and invasion by targeting miR-186-5p/HIF-1alpha in osteosarcoma. J Cell Biochem. 2019:120(4):6502-14.

127. Zhang $Y$, Liu $Y, X u X$. Knockdown of LncRNA-UCA1 suppresses chemoresistance of pediatric AML by inhibiting glycolysis through the microRNA-125a/hexokinase 2 pathway. J Cell Biochem. 2018;119(7): 6296-308.

128. Huang T, Liu HW, Chen JQ, Wang SH, Hao LQ, Liu M, et al. The long noncoding RNA PVT1 functions as a competing endogenous RNA by sponging miR-186 in gastric cancer. Biomed Pharmacother. 2017;88:302-8.
129. Wen X, Liu X, Mao YP, Yang XJ, Wang YQ, Zhang PP, et al. Long non-coding RNA DANCR stabilizes HIF-1alpha and promotes metastasis by interacting with NF90/NF45 complex in nasopharyngeal carcinoma. Theranostics. 2018; 8(20):5676-89.

130. Chi Y, Luo Q, Song Y, Yang F, Wang Y, Jin M, et al. Circular RNA circPIP5K1A promotes non-small cell lung cancer proliferation and metastasis through miR-600/HIF-1alpha regulation. J Cell Biochem. 2019;120(11):19019-30.

131. Zhai Z, Fu Q, Liu C, Zhang X, Jia P, Xia P, et al. Emerging Roles Of hsa-circ0046600 Targeting The miR-640/HIF-1alpha Signalling Pathway In The Progression Of HCC. Onco Targets Ther. 2019;12:9291-302.

132. Li Y, Zhao L, Qi Y, Yang X. MicroRNA214 upregulates HIF1alpha and VEGF by targeting ING4 in lung cancer cells. Mol Med Rep. 2019;19(6):4935-45.

133. Xue D, Yang Y, Liu Y, Wang P, Dai Y, Liu Q, et al. MicroRNA-206 attenuates the growth and angiogenesis in non-small cell lung cancer cells by blocking the 14-3-3zeta/STAT3/HIF-1alpha/NEGF signaling. Oncotarget. 2016; 7(48):79805-13.

134. Lo Dico A, Costa V, Martelli C, Diceglie C, Rajata F, Rizzo A, et al. MiR675-5p Acts on HIF-1alpha to Sustain Hypoxic Responses: A New Therapeutic Strategy for Glioma. Theranostics. 2016;6(8):1105-18.

135. Wang TH, Yu CC, Lin YS, Chen TC, Yeh CT, Liang KH, et al. Long noncoding RNA CPS1-IT1 suppresses the metastasis of hepatocellular carcinoma by regulating HIF-1alpha activity and inhibiting epithelial-mesenchymal transition. Oncotarget. 2016;7(28):43588-603.

136. Zhang XW, Bu P, Liu L, Zhang XZ, Li J. Overexpression of long non-coding RNA PVT1 in gastric cancer cells promotes the development of multidrug resistance. Biochem Biophys Res Commun. 2015;462(3):227-32.

137. Tao T, Li G, Dong Q, Liu D, Liu C, Han D, et al. Loss of SNAlL inhibits cellular growth and metabolism through the miR-128-mediated RPS6KB1/HIF1alpha/PKM2 signaling pathway in prostate cancer cells. Tumour Biol. 2014; 35(9):8543-50.

138. Zhou C, Huang C, Wang J, Huang H, Li J, Xie Q, et al. LncRNA MEG3 downregulation mediated by DNMT3b contributes to nickel malignant transformation of human bronchial epithelial cells via modulating PHLPP1 transcription and HIF-1alpha translation. Oncogene. 2017;36(27):3878-89.

139. Lin J, Cao S, Wang Y, Hu Y, Liu H, Li J, et al. Long non-coding RNA UBE2CP3 enhances HCC cell secretion of VEGFA and promotes angiogenesis by activating ERK1/2/HIF-1alpha/NEGFA signalling in hepatocellular carcinoma. J Exp Clin Cancer Res. 2018;37(1):113.

140. Chen S, Xue Y, Wu X, Le C, Bhutkar A, Bell EL, et al. Global microRNA depletion suppresses tumor angiogenesis. Genes Dev. 2014;28(10):1054-67.

141. Zhang L, Sun ZJ, Bian Y, Kulkarni AB. MicroRNA-135b acts as a tumor promoter by targeting the hypoxia-inducible factor pathway in genetically defined mouse model of head and neck squamous cell carcinoma. Cancer Lett. 2013;331(2):230-8.

142. Wang M, Wang W, Wang J, Zhang J. MiR-182 promotes glucose metabolism by upregulating hypoxia-inducible factor 1alpha in NSCLC cells. Biochem Biophys Res Commun. 2018;504(2):400-5

143. Chen T, Yao LQ, Shi Q, Ren Z, Ye LC, Xu JM, et al. MicroRNA-31 contributes to colorectal cancer development by targeting factor inhibiting HIF-1alpha (FIH-1). Cancer Biol Ther. 2014;15(5):516-23.

144. Jia YY, Zhao JY, Li BL, Gao K, Song Y, Liu MY, et al. miR-592/WSB1/HIF1alpha axis inhibits glycolytic metabolism to decrease hepatocellular carcinoma growth. Oncotarget. 2016;7(23):35257-69.

145. Zhang H, Guo X, Feng X, Wang T, Hu Z, Que X, et al. MiRNA-543 promotes osteosarcoma cell proliferation and glycolysis by partially suppressing PRMT9 and stabilizing HIF-1alpha protein. Oncotarget. 2017;8(2):2342-55.

146. Tanaka H, Sasayama T, Tanaka K, Nakamizo S, Nishihara M, Mizukawa K, et al. MicroRNA-183 upregulates HIF-1alpha by targeting isocitrate dehydrogenase 2 (IDH2) in glioma cells. J Neurooncol. 2013;111(3):273-83.

147. Chen L, Han L, Zhang K, Shi Z, Zhang J, Zhang A, et al. VHL regulates the effects of miR-23b on glioma survival and invasion via suppression of HIF1alpha/VEGF and beta-catenin/Tcf-4 signaling. Neuro Oncol. 2012;14(8): 1026-36.

148. Yin Y, Yan ZP, Lu NN, Xu Q, He J, Qian X, et al. Downregulation of miR-145 associated with cancer progression and VEGF transcriptional activation by targeting N-RAS and IRS1. Biochim Biophys Acta. 2013;1829(2):239-47.

149. Liu MM, Li Z, Han XD, Shi JH, Tu DY, Song W, et al. MiR-30e inhibits tumor growth and chemoresistance via targeting IRS1 in Breast Cancer. Sci Rep. 2017;7(1):15929.

150. Chai ZT, Kong J, Zhu XD, Zhang YY, Lu L, Zhou JM, et al. MicroRNA-26a inhibits angiogenesis by down-regulating VEGFA through the PIK3C2alpha/ 
Akt/HIF-1alpha pathway in hepatocellular carcinoma. PLoS One. 2013;8(10): e77957.

151. Yang Z, Han Y, Cheng K, Zhang G, Wang X. miR-99a directly targets the mTOR signalling pathway in breast cancer side population cells. Cell Prolif. 2014;47(6):587-95.

152. Sun YW, Chen YF, Li J, Huo YM, Liu DJ, Hua R, et al. A novel long noncoding RNA ENST00000480739 suppresses tumour cell invasion by regulating OS-9 and HIF-1alpha in pancreatic ductal adenocarcinoma. Br J Cancer. 2014;111(11):2131-41.

153. Monteleone F, Taverna S, Alessandro R, Fontana S. SWATH-MS based quantitative proteomics analysis reveals that curcumin alters the metabolic enzyme profile of CML cells by affecting the activity of miR-22/PO7/HIF1alpha axis. J Exp Clin Cancer Res. 2018;37(1):170.

154. Corrado C, Costa V, Giavaresi G, Calabrese A, Conigliaro A, Alessandro R. Long Non Coding RNA H19: A New Player in Hypoxia-Induced Multiple Myeloma Cell Dissemination. Int J Mol Sci. 2019;20(4).

155. Shih JW, Chiang WF, Wu ATH, Wu MH, Wang LY, Yu YL, et al. Long noncoding RNA LnCHIFCAR/MIR31HG is a HIF-1alpha co-activator driving oral cancer progression. Nat Commun. 2017;8:15874.

156. Yeh CC, Luo JL, Nhut Phan N, Cheng YC, Chow LP, Tsai MH, et al. Different effects of long noncoding RNA NDRG1-OT1 fragments on NDRG1 transcription in breast cancer cells under hypoxia. RNA Biol. 2018;15(12): 1487-98.

157. Ozer A, Wu LC, Bruick RK. The candidate tumor suppressor ING4 represses activation of the hypoxia inducible factor (HIF). Proc Natl Acad Sci U S A. 2005;102(21):7481-6.

158. Jiang BH, Jiang G, Zheng JZ, Lu Z, Hunter T, Vogt PK. Phosphatidylinositol 3kinase signaling controls levels of hypoxia-inducible factor 1. Cell Growth Differ. 2001;12(7):363-9.

159. Hu Y, Zhu Q, Tang L. MiR-99a antitumor activity in human breast cancer cells through targeting of mTOR expression. PLoS One. 2014;9(3):e92099

160. Baek JH, Mahon PC, Oh J, Kelly B, Krishnamachary B, Pearson M, et al. OS-9 interacts with hypoxia-inducible factor 1alpha and prolyl hydroxylases to promote oxygen-dependent degradation of HIF-1alpha. Mol Cell. 2005;17(4): 503-12.

161. Chachami G, Paraskeva E, Mingot JM, Braliou GG, Gorlich D, Simos G Transport of hypoxia-inducible factor HIF-1alpha into the nucleus involves importins 4 and 7. Biochem Biophys Res Commun. 2009:390(2):235-40.

162. Joshi HP, Subramanian IV, Schnettler EK, Ghosh G, Rupaimoole R, Evans C, et al. Dynamin 2 along with microRNA-199a reciprocally regulate hypoxiainducible factors and ovarian cancer metastasis. Proc Natl Acad Sci U S A. 2014;111(14):5331-6.

163. Lei Z, Li B, Yang Z, Fang H, Zhang GM, Feng ZH, et al. Regulation of HIFlalpha and VEGF by miR-20b tunes tumor cells to adapt to the alteration of oxygen concentration. PLoS One. 2009:4(10):e7629.

164. Khella HW, Scorilas A, Mozes R, Mirham L, Lianidou E, Krylov SN, et al. Low expression of miR-126 is a prognostic marker for metastatic clear cell renal cell carcinoma. Am J Pathol. 2015;185(3):693-703.

165. Slaby O, Redova M, Poprach A, Nekvindova J, lliev R, Radova L, et al. Identification of MicroRNAs associated with early relapse after nephrectomy in renal cell carcinoma patients. Genes Chromosomes Cancer. 2012;51(7): 707-16.

166. Liu W, Chen H, Wong N, Haynes W, Baker CM, Wang X. Pseudohypoxia induced by miR-126 deactivation promotes migration and therapeutic resistance in renal cell carcinoma. Cancer Lett. 2017:394:65-75.

167. Puissegur MP, Mazure NM, Bertero T, Pradelli L, Grosso S, Robbe-Sermesant $\mathrm{K}$, et al. miR-210 is overexpressed in late stages of lung cancer and mediates mitochondrial alterations associated with modulation of HIF-1 activity. Cell Death Differ. 2011;18(3):465-78.

168. Grosso S, Doyen J, Parks SK, Bertero T, Paye A, Cardinaud B, et al. MiR-210 promotes a hypoxic phenotype and increases radioresistance in human lung cancer cell lines. Cell Death Dis. 2013;4:e544.

169. Costales MG, Haga CL, Velagapudi SP, Childs-Disney JL, Phinney DG, Disney MD. Small Molecule Inhibition of microRNA-210 Reprograms an Oncogenic Hypoxic Circuit. J Am Chem Soc. 2017;139(9):3446-55.

170. Li Y, Zhang D, Wang X, Yao X, Ye C, Zhang S, et al. Hypoxia-inducible miR182 enhances HIF1alpha signaling via targeting PHD2 and FIH1 in prostate cancer. Sci Rep. 2015;5:12495.

171. Wang XJ, Zhang DL, Fu C, Wei BZ, Li GJ. MiR-183 modulates multi-drug resistance in hepatocellular cancer (HCC) cells via miR-183-IDH2/SOCS6-HIF1alpha feedback loop. Eur Rev Med Pharmacol Sci. 2016;20(10):2020-7.
172. Luo F, Liu X, Ling M, Lu L, Shi L, Lu X, et al. The IncRNA MALAT1, acting through HIF-1alpha stabilization, enhances arsenite-induced glycolysis in human hepatic L-02 cells. Biochim Biophys Acta. 2016;1862(9):1685-95.

173. Ikeda S, Kitadate A, Abe F, Takahashi N, Tagawa H. Hypoxia-inducible KDM3A addiction in multiple myeloma. Blood Adv. 2018;2(4):323-34.

174. Wouters BG, Koritzinsky M. Hypoxia signalling through mTOR and the unfolded protein response in cancer. Nat Rev Cancer. 2008;8(11):851-64.

175. Malakar P, Shilo A, Mogilevsky A, Stein I, Pikarsky E, Nevo Y, et al. Long Noncoding RNA MALAT1 Promotes Hepatocellular Carcinoma Development by SRSF1 Upregulation and mTOR Activation. Cancer Res. 2017;77(5):1155-67.

176. Zhang ZC, Tang C, Dong Y, Zhang J, Yuan T, Tao SC, et al. Targeting the long noncoding RNA MALAT1 blocks the pro-angiogenic effects of osteosarcoma and suppresses tumour growth. Int J Biol Sci. 2017;13(11): 1398-408.

177. Tong J, Xu X, Zhang Z, Ma C, Xiang R, Liu J, et al. Hypoxia-induced long non-coding RNA DARS-AS1 regulates RBM39 stability to promote myeloma malignancy. Haematologica. 2019.

178. Yang F, Zhang H, Mei Y, Wu M. Reciprocal regulation of HIF-1alpha and lincRNA-p21 modulates the Warburg effect. Mol Cell. 2014;53(1):88-100.

179. Chen F, Chen J, Yang L, Liu J, Zhang X, Zhang Y, et al. Extracellular vesiclepackaged HIF-1alpha-stabilizing IncRNA from tumour-associated macrophages regulates aerobic glycolysis of breast cancer cells. Nat Cell Biol. 2019;21(4):498-510.

180. Bartoszewska S, Kochan K, Piotrowski A, Kamysz W, Ochocka RJ, Collawn JF, et al. The hypoxia-inducible miR-429 regulates hypoxia-inducible factorlalpha expression in human endothelial cells through a negative feedback loop. FASEB J. 2015;29(4):1467-79.

181. Niu Y, Jin Y, Deng SC, Deng SJ, Zhu S, Liu Y, et al. MiRNA-646-mediated reciprocal repression between HIF-1alpha and MIIP contributes to tumorigenesis of pancreatic cancer. Oncogene. 2018;37(13):1743-58.

182. Wang J, Chen J, Chang P, LeBlanc A, Li D, Abbruzzesse JL, et al. MicroRNAs in plasma of pancreatic ductal adenocarcinoma patients as novel bloodbased biomarkers of disease. Cancer Prev Res (Phila). 2009;2(9):807-13.

183. Sabry D, El-Deek SEM, Maher M, El-Baz MAH, El-Bader HM, Amer E, et al. Role of miRNA-210, miRNA-21 and miRNA-126 as diagnostic biomarkers in colorectal carcinoma: impact of HIF-1alpha-VEGF signaling pathway. Mol Cell Biochem. 2019;454(1-2):177-89.

184. Chang RM, Xu JF, Fang F, Yang H, Yang LY. MicroRNA-130b promotes proliferation and EMT-induced metastasis via PTEN/p-AKT/HIF-1alpha signaling. Tumour Biol. 2016;37(8):10609-19.

185. Ge X, Liu X, Lin F, Li P, Liu K, Geng R, et al. MicroRNA-421 regulated by HIF1alpha promotes metastasis, inhibits apoptosis, and induces cisplatin resistance by targeting E-cadherin and caspase-3 in gastric cancer. Oncotarget. 2016;7(17):24466-82.

186. Hu J, Wang XF. HIF-miR-215-KDM1B promotes glioma-initiating cell adaptation to hypoxia. Cell Cycle. 2016;15(15):1939-40.

187. Toyama T, Kondo N, Endo Y, Sugiura H, Yoshimoto N, Iwasa M, et al. High expression of microRNA-210 is an independent factor indicating a poor prognosis in Japanese triple-negative breast cancer patients. Jpn I Clin Oncol. 2012;42(4):256-63.

188. Gomez-Maldonado L, Tiana M, Roche O, Prado-Cabrero A, Jensen L, Fernandez-Barral A, et al. EFNA3 long noncoding RNAs induced by hypoxia promote metastatic dissemination. Oncogene. 2015;34(20):2609-20.

189. Ke HL, Li WM, Lin HH, Hsu WC, Hsu YL, Chang LL, et al. Hypoxia-regulated MicroRNA-210 Overexpression is Associated with Tumor Development and Progression in Upper Tract Urothelial Carcinoma. Int J Med Sci. 2017;14(6): $578-84$.

190. Saenz-de-Santa-Maria I, Bernardo-Castineira C, Secades P, Bernaldo-deQuiros S, Rodrigo JP, Astudillo A, et al. Clinically relevant HIF-1alphadependent metabolic reprogramming in oropharyngeal squamous cell carcinomas includes coordinated activation of CAIX and the miR-210/ISCU signaling axis, but not MCT1 and MCT4 upregulation. Oncotarget. 2017:8(8): 13730-46.

191. Qu S, Yang X, Li X, Wang J, Gao Y, Shang R, et al. Circular RNA: A new star of noncoding RNAs. Cancer Lett. 2015;365(2):141-8.

192. Rustum YM, Chintala S, Durrani FA, Bhattacharya A. Non-Coding Micro RNAs and Hypoxia-Inducible Factors Are Selenium Targets for Development of a Mechanism-Based Combination Strategy in Clear-Cell Renal Cell CarcinomaBench-to-Bedside Therapy. Int J Mol Sci. 2018;19(11):3378.

193. Bao B, Ali S, Ahmad A, Azmi AS, Li Y, Banerjee S, et al. Hypoxia-induced aggressiveness of pancreatic cancer cells is due to increased expression of 
VEGF, IL-6 and miR-21, which can be attenuated by CDF treatment. PLoS One. 2012;7(12):e50165.

194. Isanejad A, Alizadeh AM, Amani Shalamzari S, Khodayari H, Khodayari S, Khori V, et al. MicroRNA-206, let-7a and microRNA-21 pathways involved in the anti-angiogenesis effects of the interval exercise training and hormone therapy in breast cancer. Life Sci. 2016;151:30-40.

195. Bertozzi D, Marinello J, Manzo SG, Fornari F, Gramantieri L, Capranico G. The natural inhibitor of DNA topoisomerase I, camptothecin, modulates HIF1alpha activity by changing miR expression patterns in human cancer cells. Mol Cancer Ther. 2014;13(1):239-48.

196. Qi P, Du X. The long non-coding RNAs, a new cancer diagnostic and therapeutic gold mine. Mod Pathol. 2013;26(2):155-65.

197. Li CH, Chen Y. Targeting long non-coding RNAs in cancers: progress and prospects. Int J Biochem Cell Biol. 2013;45(8):1895-910.

198. Kole R, Krainer AR, Altman S. RNA therapeutics: beyond RNA interference and antisense oligonucleotides. Nat Rev Drug Discov. 2012;11(2):125-40.

\section{Publisher's Note}

Springer Nature remains neutral with regard to jurisdictional claims in published maps and institutional affiliations.

Ready to submit your research? Choose BMC and benefit from:

- fast, convenient online submission

- thorough peer review by experienced researchers in your field

- rapid publication on acceptance

- support for research data, including large and complex data types

- gold Open Access which fosters wider collaboration and increased citations

- maximum visibility for your research: over $100 \mathrm{M}$ website views per year

At BMC, research is always in progress.

Learn more biomedcentral.com/submissions 